\title{
Effigy Pottery in the Joint Educational Consortium's Hodges Collection
}

Mary B. Trubitt

Arkansas Archeological Survey, HSU Research Station

Follow this and additional works at: https://scholarworks.sfasu.edu/ita

Part of the American Material Culture Commons, Archaeological Anthropology Commons, Environmental Studies Commons, Other American Studies Commons, Other Arts and Humanities Commons, Other History of Art, Architecture, and Archaeology Commons, and the United States History Commons

Tell us how this article helped you.

This Article is brought to you for free and open access by the Center for Regional Heritage Research at SFA ScholarWorks. It has been accepted for inclusion in Index of Texas Archaeology: Open Access Gray Literature from the Lone Star State by an authorized editor of SFA ScholarWorks. For more information, please contact cdsscholarworks@sfasu.edu. 


\section{Effigy Pottery in the Joint Educational Consortium's Hodges Collection}

Creative Commons License

(c) (i) (8)

This work is licensed under a Creative Commons Attribution-NonCommercial 4.0 International License 


\title{
Effigy Pottery in the Joint Educational Consortium's Hodges Collection
}

\author{
Mary Beth Trubitt \\ Arkansas Archeological Survey, HSU Research Station
}

As part of on-going documentation of the Joint Educational Consortium's Hodges Collection, 31 ceramic effigy vessels or vessel fragments are described. Most were dug by Thomas and Charlotte Hodges or Vere Huddleston in the 1930s-1940s from sites in the Middle Ouachita archeological region of southwest Arkansas. By documenting these vessels and what is known of their archeological contexts, we can better employ them in future analyses of regional variation, iconography, and interactions between the Caddo Area and the Mississippian Southeast.

\section{Introduction}

The Joint Educational Consortium (JEC), made up of Henderson State University and Ouachita Baptist University, owns a large collection of Native American artifacts curated at the Arkansas Archeological Survey's Henderson State University (ARAS/HSU) Research Station in Arkadelphia. This collection was amassed by Thomas and Charlotte Hodges in the 1930s and 1940s from archeological sites near Arkadelphia. The Hodgeses, along with other local amateurs such as Robert Proctor and Vere Huddleston, were involved in the development of Caddo Area archeology alongside the few professional archeologists working in this area in the early to mid- twentieth century, such as Philip Phillips and Alex D. Krieger (Early 1986; Girard et al. 2014). The Hodgeses were active participants in early Caddo Conferences and they and Huddleston wrote articles for publication (e.g., Hodges and Hodges 1945; Huddleston 1943). Proctor donated his collection to the HSU Museum (now on long-term loan to Historic Arkansas Museum in Little Rock, http://www. historicarkansas.org/). The Hodgeses bought the Menard mound site in a preservation effort and assisted Phillips' research there (Phillips et al. 1951); now known as the Menard-Hodges site (3AR4), it is part of the National Park Service's Osotouy Unit of the Arkansas Post National Memorial. Krieger and Phillips photographed ceramic vessels in both the Hodges and Huddleston collections for later study and publication (e.g., Suhm and Jelks 1962).

After the Joint Educational Consortium acquired the Hodges Collection in 1977, Ann Early and her staff at the ARAS/HSU Research Station accessioned, catalogued, and photographed artifacts. There are about 50,000 objects in the collection, mostly chipped stone tools and ceramic sherds, but also including about 1,350 whole, reconstructed, and partial or unreconstructed ceramic vessels. Early was able to identify site locations for some of the artifacts using the limited records (including Phillips' photographs and photo cards). Vere Huddleston's collection was purchased by Thomas and Charlotte Hodges, and Huddleston's notes provide some context for a subset of the artifacts in the JEC Hodges Collection. Pottery and other objects can be tied to specific known archeological sites - in some cases to specific graves - using Huddleston's notes and the Hodges catalog (Trubitt and Evans 2015). Our long-term project to document these artifacts at the ARAS/HSU Research Station provides information to officials from the JEC and the Caddo Nation as they consult about the Hodges Collection. We have developed exhibits to interpret Caddo Indian history and lifeways in the Middle Ouachita River valley using objects from the collection. Our understanding of changes in material culture, settlement patterns, and regional interaction comes in part from studying the artifacts in this collection that can be tied to known archeological sites, many of which have been damaged or destroyed by flooding, farming, or development since the 1930s.

This article describes ceramic effigy vessels, which make up a small portion of the JEC Hodges Collection pottery. Effigy vessels are representations of humans or animals modeled in pottery, including rim and "tail-riding" effigy bowls, whole vessel effigies, and quadruped forms (Phillips et al. 1951:160-169). While there are fewer animal forms than seen from the Mississippi River valley, effigies representing humans, birds, fish, reptiles and amphibians, and mammals are present in the JEC Hodges Collection. Not included as effigies in this discussion are square or triangular "boatshaped" vessels or free-standing figurines.

Documenting the effigy vessels was completed with the assistance of HSU student Emily Miller, who also created a brochure in 2014 to accompany an exhibit of effigy pottery in HSU's Huie Library. This effort has also been motivated by the Mississippian Iconography Workshop organized by Kent Reilly, specifically by the Caddo working group in 2014 (Eloise Gadus, Julie Holt, John Kelly, Duncan McKinnon, Eric Singleton, and Mary Beth Trubitt). Our discussions about Caddo 
iconography started with imagery on Caddo ceramics from East Texas and Oklahoma (e.g., Dowd 2011; Gadus 2013), moved to distinctive Red River valley zoomorphic pendants of shell and stone (McKinnon 2015), brought in iconography on engraved shell from Spiro (Phillips and Brown 1978, 1984), and returned to ceramic effigies and possible ties between more representational and more stylized designs on ceramics and in other media. Here, I focus on Caddo effigy pottery.

Following Knight (2013), the first step in iconographic analysis is to assemble the corpus of objects/images, along with information about their archeological contexts. Context is important for addressing questions of function as well as temporal change and spatial distribution. Effigy pottery is an uncommon category in the Caddo Area. Effigy vessels made up only one percent of Caddo vessels documented in Texas Archeological Research Laboratory collections (Perttula and Selden 2015:1). Here, we provide documentation on 31 effigy vessels or fragments, about 2 percent of the JEC Hodges Collection vessel assemblage. With only a few examples, we get a sense of uniqueness and style variation (Knight 2013:34). But with additional examples - drawn from ARAS/ HSU Research Station photograph files as well as from published sources - we can begin to recognize patterns. Stylistic and iconographic analysis are later steps. Here, the goal is to provide documentation of the effigy vessels in the JEC Hodges Collection for the wider community of researchers, descendants, and other interested readers.

\section{The JEC Hodges Collection Effigy Pottery}

A total of 31 effigy vessels and vessel fragments have been documented from the JEC Hodges Collection (see Appendix). Excluded from this discussion is a small bird effigy vessel that is likely an early twentieth century piece from the Southwestern U.S. Also excluded are two figurine fragments collected by the Hodgeses at the Mississippian period Menard-Hodges mound center (3AR4). These appear to be figurines rather than broken attachments from effigy vessel handles, and are part of a small set of artifacts in the JEC Hodges Collection from the lower Arkansas River valley (see Trubitt 2016). The figurine fragments, a "teapot" bottle, and several other pottery vessels collected by the Hodgeses from the Menard vicinity will be described in a future article.

The JEC Hodges Collection was accessioned in 1977 (ARAS accession number 77-1). Based on available catalogs/notes, artifacts identified to specific sites by Ann Early were coded with numbers representing the site and object (e.g., 1-5, where 1 codes for site 3CL21 and 5 codes for a specific artifact catalogued from that site; artifacts with unknown site provenience were coded as X). Many of the artifacts have inked numbers that correspond to either the original Huddleston or Hodges catalogs, and some had been reconstructed or restored by Vere Huddleston or Thomas and Charlotte Hodges in the 1930s-1940s. Copies of Phillips' 1939 photographs and notes on part of the collection aided identification. Images of some of these vessels have been previously published, forming part of the known corpus of Caddo pottery (e.g., Suhm and Jelks 1962:Plate 25).

The effigy vessels have been documented using a protocol first developed by Ann Early for use on HSU Museum vessel collections and recently revised by Early and Leslie Walker (2014) as part of the Arkansas Archeological Survey's digital vessel database initiative. The record form includes attributes of form and shape, paste and temper, measurements, decorative treatment, evidence of use, and associations. While there have been some changes in the recording protocol between 2000 and 2016, the results are comparable. Decorative treatments to vessel rim and body are coded using the collegiate or descriptive system, developed for use on Caddo vessels in southern Arkansas (e.g., Early 1993; Schambach and Miller 1984), with named patterns and numbered design variations within each pattern. Type (and variety) names follow Early (1993) and Suhm and Jelks (1962).

Documentation of site collections that include Huddleston vessels and records have been prioritized, since in some cases grave lots can be reconstructed (Trubitt and Evans 2015). For purposes of advising the JEC in their on-going consultation about the Hodges Collection with descendant communities, an effort has been made to identify associated funerary objects and unassociated funerary objects using available notes, catalogues, and records from the 1930s-1940s. Two of the effigies from Huddleston's East Place (3CL21) excavations were previously discussed and illustrated with their grave lots (Trubitt and Evans 2015:Fig. 7, 8): vessel 1-14, an East Incised rim effigy bowl, was part of an East phase (ca. A.D. 1150-1400) grave dug in 1942; and vessel 1-50, a Keno Trailed human effigy bottle, was part of a late Social Hill or Deceiper phase (ca. A.D. 1600-1700) grave dug in 1939. The East phase grave also contained two other rim effigy bowls Huddleston gave to his associates Proctor and Richardson; these were illustrated previously (Suhm and Jelks 1962:Plate 21E; Trubitt and Evans 2015:Fig. 4) but are not present in the HSU Museum collection. Several other effigies in the JEC Hodges Collection have been linked to grave lots from sites 3CL23, 3CL40, 3CL81, 3CL83, 3HS104, and 3HS105 (Table 1, Figures 1 and 2). One effigy vessel (77-1/3-9, site 3CL83) has been identified as an associated funerary object. 


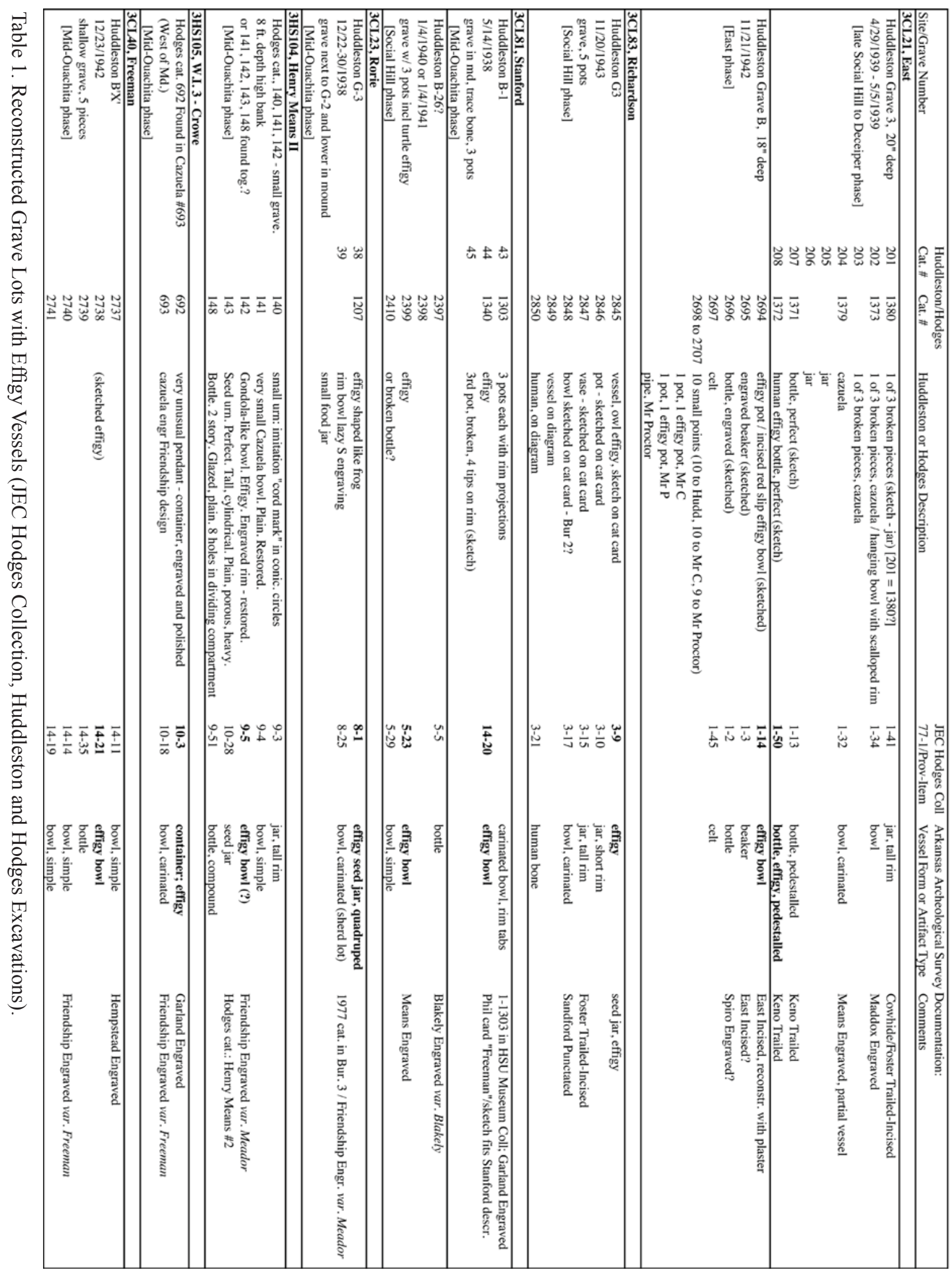




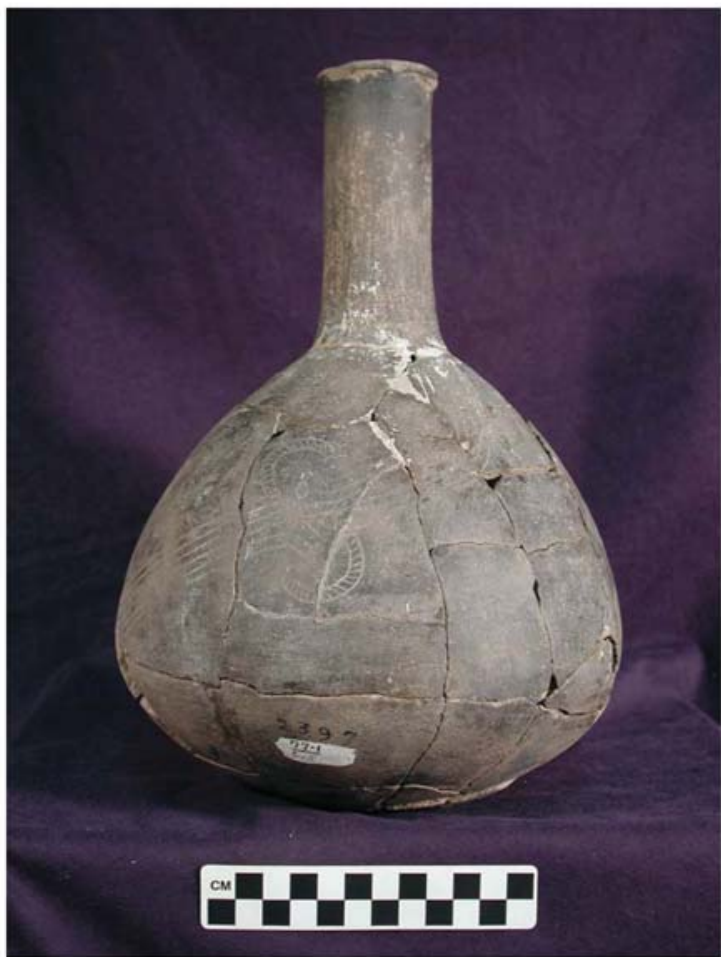

B-26?

$77-1 / 5-5,23,29$
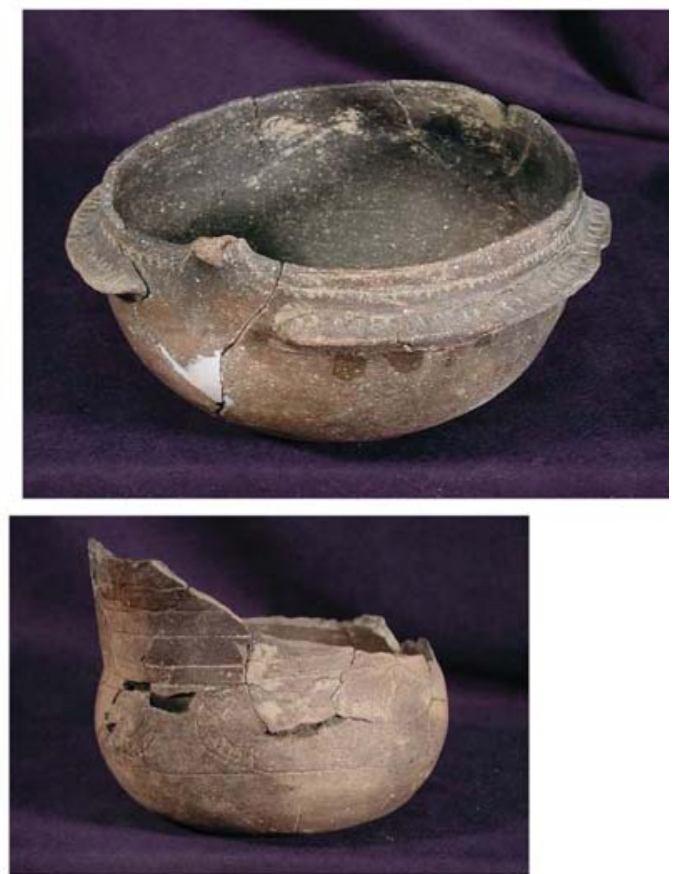

Figure 1. Vessels from Huddleston's B-26?, 3CL81.

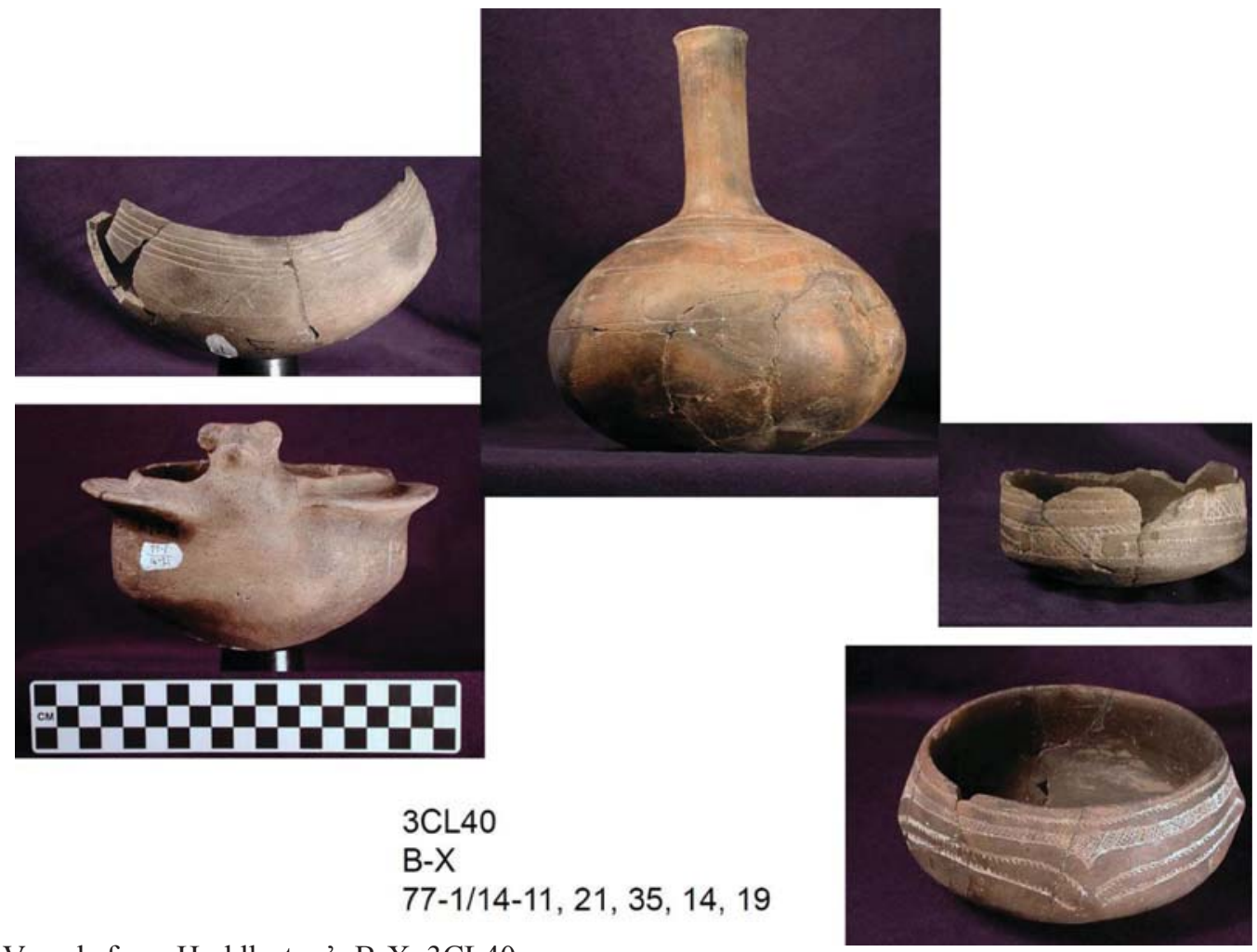

Figure 2. Vessels from Huddleston's B-X, 3CL40. 


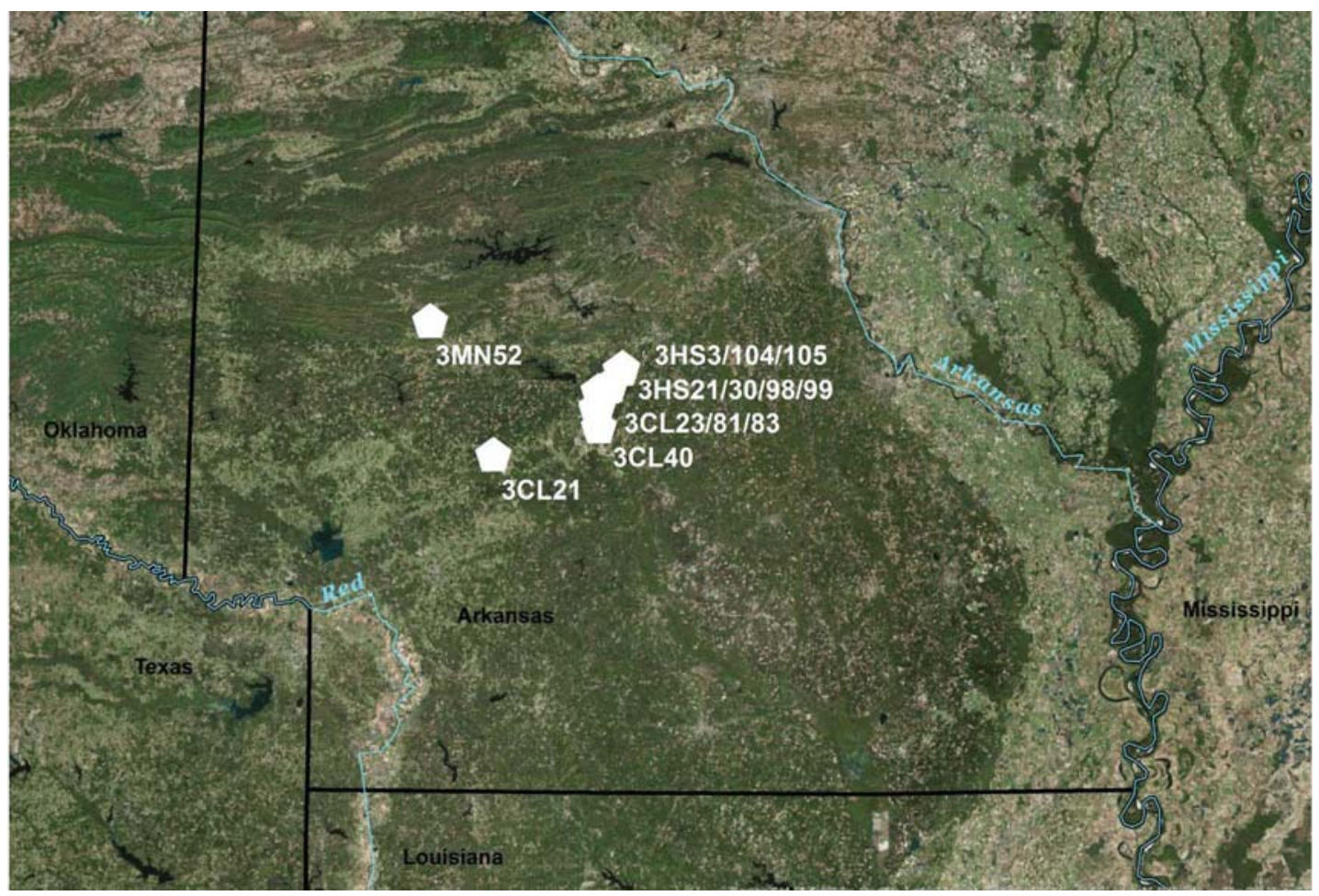

Figure 3. Map showing locations of archeological sites with Hodges Collection effigy vessels discussed in article (base map: ArcGIS World Imagery, ESRI 2014).

When seen from the perspective of other grave goods as grave lots, these effigies can be placed more firmly into their cultural context and in time and space. Spatially, most of the effigies came from sites along the Ouachita River in the Middle Ouachita archeological region in Arkansas (Figure 3). Two effigies came from a site on the Antoine River in the Little Missouri archeological region, and one was reportedly collected from a Montgomery County site in the Ouachita Mountains archeological region. These effigy vessels represent a chronological range through the Caddo period, with characteristics that place the Middle Ouachita region examples from the East phase (ca. A.D 1150-1400) to the Deceiper phase (ca. A.D. 1650-1700) (Early 1993).

Vessel forms include bowls $(\mathrm{n}=18)$, bottles $(n=5)$, seed jars $(n=4)$, and "container" $(n=1)$; handle fragments $(\mathrm{n}=3)$ probably were originally part of effigy bowls (Table 2). While some vessels show some wear on base and around rim/neck or on handle tabs, sooting was not noted on most examples (compare with House 2003:33). Effigy vessels were made of clay tempered with a mixture of grog (crushed sherds) and mussel shell $(\mathrm{n}=15)$, or tempered with just grog $(n=8)$, just shell $(n=7)$, or shell with bone $(n=1)$. In the Middle Ouachita region, mussel shell was used as temper beginning in late 1300 s or early 1400 s during the Mid-Ouachita phase, and was the predominant temper after A.D. 1500 during the Social Hill and Deceiper phases (Perttula et al. 2011).

The effigies are often formed with unique modeled or appliqued handles, heads, flanges, and legs. Some include incising or engraving, such as horizontal lines with or without ticking below the rim (incised Bates and Barrington patterns, engraved Erie and Elgin patterns), crosshatched facial features or rim panels (engraved Edgar, Elwyn, and Elmira patterns), or circles, scrolls, or curvilinear designs on body (incised Baker and Belhaven patterns, engraved Edith and Elmhurst patterns). Identified types in the collection include East Incised, Friendship Engraved, Garland Engraved, Means Engraved, and Keno Trailed.

Effigies include what Phillips, Ford, and Griffin (1951:160-169) term rim effigy bowls with head and tail tabs, as well as whole vessel effigies and quadruped forms. Representations of both humans and animals can be seen in the effigies (Figure 4). While it is tempting to identify birds, fish, bears, or other animals portrayed 


\begin{tabular}{|c|c|c|c|c|c|c|c|}
\hline Item No. & Site No. & Vessel Form & Type & Temporal phase & Decoration & Rim :: Body & Temper \\
\hline $10-3$ & $3 \mathrm{HS} 105$ & container, effigy (?) & Garland Engraved & Mid-Ouachita & engraved & :: Elmira 30? & $\begin{array}{l}\text { SHELL (LEACHED) \& GROG, } \\
\text { FINE/SPARSE }\end{array}$ \\
\hline $21-136$ & 3HS98 & effigy bottle & $\begin{array}{l}\text { Keno Trailed / Means } \\
\text { Engraved }\end{array}$ & Deceiper & $\begin{array}{l}\text { incised/engraved/ } \\
\text { appliqued/modeled }\end{array}$ & plain :: Baker 27? & $\begin{array}{l}\text { SHELL (LEACHED) \& GROG, } \\
\text { FINE/SPARSE }\end{array}$ \\
\hline $\mathrm{X}-187$ & unknown & effigy bottle & Means Engraved & & $\begin{array}{l}\text { engraved/appliqued/ } \\
\text { modeled/punctated }\end{array}$ & plain :: Belhaven? & $\begin{array}{l}\text { SHELL (LEACHED), } \\
\text { MEDIUM/SPARSE }\end{array}$ \\
\hline $1-50$ & $3 \mathrm{CL} 21$ & $\begin{array}{l}\text { effigy bottle, } \\
\text { pedestalled }\end{array}$ & Keno Trailed & Social Hill/Deceiper & $\begin{array}{l}\text { incised/trailed/modeled/ } \\
\text { appliqued }\end{array}$ & plain :: Baker 27? & $\begin{array}{l}\text { SHELL (LEACHED), MEDIUM TO } \\
\text { COARSE/ABUNDANT }\end{array}$ \\
\hline $32-1$ & 3MN52 & $\begin{array}{l}\text { effigy bottle, } \\
\text { quadruped }\end{array}$ & Authenticity uncertain & & appliqued/modeled & & SHELL, COARSE/ABUNDANT \\
\hline $\mathrm{X}-186$ & unknown & $\begin{array}{l}\text { effigy bottle, } \\
\text { quadruped }\end{array}$ & Means Engraved & & $\begin{array}{l}\text { engraved/incised/ } \\
\text { appliqued/modeled }\end{array}$ & plain :: Edith? & $\begin{array}{l}\text { SHELL (LEACHED), } \\
\text { MEDIUM/ABUNDANT }\end{array}$ \\
\hline $1-14$ & $3 \mathrm{CL} 21$ & effigy bowl & East Incised & East & $\begin{array}{l}\text { red slipped/incised/ } \\
\text { modeled }\end{array}$ & $\begin{array}{l}\text { Bates } 15 \text { or Barrington } 5:: \\
\text { plain }\end{array}$ & GROG, FINE TO MEDIUM \\
\hline $5-23$ & 3 CL81 & effigy bowl & Means Engraved & Social Hill & $\begin{array}{l}\text { engraved/appliqued } \\
\text { flange/handles }\end{array}$ & Elgin 1 :: plain & $\begin{array}{l}\text { SHELL (SOME LEACHED), } \\
\text { FINE/ABUNDANT }\end{array}$ \\
\hline 9-24 & $3 \mathrm{HS} 104$ & effigy bowl & & & $\begin{array}{l}\text { engraved/modeled// } \\
\text { appliqued }\end{array}$ & Erie 4 :: plain & GROG \\
\hline $10-1$ & $3 \mathrm{HS} 105$ & effigy bowl & Garland Engraved & Mid-Ouachita & $\begin{array}{l}\text { engraved/modeled/ } \\
\text { appliqued }\end{array}$ & Erie $12::$ Elmira 33 or $36 ?$ & $\begin{array}{l}\text { GROG \& SHELL (LEACHED), } \\
\text { MEDIUM/ABUNDANT }\end{array}$ \\
\hline $14-20$ & $3 \mathrm{CL} 81$ & effigy bowl & & Mid-Ouachita & appliqued handles & & $\begin{array}{l}\text { GROG \& SHELL (LEACHED), } \\
\text { ABUNDANT }\end{array}$ \\
\hline $14-21$ & $3 \mathrm{CL} 40$ & effigy bowl & & Mid-Ouachita & appliqued flange/modeled & & $\begin{array}{l}\text { GROG \& SHELL (LEACHED), } \\
\text { FINE/ABUNDANT }\end{array}$ \\
\hline $18-1$ & $\begin{array}{l}\text { unknown, Hot } \\
\text { Spring County }\end{array}$ & effigy bowl & & & $\begin{array}{l}\text { engraved/appliqued/ } \\
\text { modeled }\end{array}$ & Bates 2 :: plain & $\begin{array}{l}\text { GROG \& SHELL (LEACHED), } \\
\text { FINE/SPARSE }\end{array}$ \\
\hline $21-69$ & 3HS98 & effigy bowl & & & $\begin{array}{l}\text { engraved/incised/ } \\
\text { appliqued }\end{array}$ & & $\begin{array}{l}\text { SHELL( LEACHED) \& GROG, } \\
\text { FINE/ABUNDANT }\end{array}$ \\
\hline $21-72$ & $3 \mathrm{HS} 98$ & effigy bowl & & & $\begin{array}{l}\text { engraved/appliqued/ } \\
\text { modeled }\end{array}$ & Erie 13 :: plain & GROG, COARSE/ABUNDANT \\
\hline $39-1$ & 3HS2I & effigy bowl & & & appliqued/modeled & & $\begin{array}{l}\text { GROG \& SHELL (LEACHED), } \\
\text { MEDIUM/ABUNDANT }\end{array}$ \\
\hline $\mathrm{x}-32$ & unknown & effigy bowl & & & modeled/appliqued & & $\begin{array}{l}\text { GROG \& SHELL (LEACHED), } \\
\text { COARSE/ABUNDANT }\end{array}$ \\
\hline $\mathrm{X}-34$ & unknown & effigy bowl & & & $\begin{array}{l}\text { modeled/appliqued/ } \\
\text { engraved }\end{array}$ & & SHELL \& GROG, MEDIUM \\
\hline $\mathrm{X}-58$ & unknown & effigy bowl & & & modeled/appliqued/incised & & GROG, MEDIUM \\
\hline $9-5$ & $3 \mathrm{HS} 104$ & effigy bowl (?) & $\begin{array}{l}\text { Friendship Engraved } \\
\text { var. Meador }\end{array}$ & Mid-Ouachita & $\begin{array}{l}\text { engraved/appliqued } \\
\text { handles }\end{array}$ & Elwyn 7 :: plain & $\begin{array}{l}\text { SHELL (LEACHED) \& GROG, } \\
\text { FINE/ABUNDANT }\end{array}$ \\
\hline $14-49$ & 3 CL40 & effigy bowl (?) & Means Engraved & & $\begin{array}{l}\text { engraved/appliqued } \\
\text { handles }\end{array}$ & Elgin $2::$ plain & $\begin{array}{l}\text { SHELL (SOME LEACHED) \& GROG, } \\
\text { FINE/SPARSE }\end{array}$ \\
\hline $24-1$ & 3HS99 & effigy bowl (?) & & & & & $\begin{array}{l}\text { SHELL (LEACHED), } \\
\text { MEDIUM/ABUNDANT }\end{array}$ \\
\hline$x-68$ & unknown & effigy bowl (?) & & & appliqued & & $\begin{array}{l}\text { SHELL (LEACHED) \& BONE?, } \\
\text { ABUNDANT }\end{array}$ \\
\hline 34 & $3 \mathrm{HS} 30$ & \begin{tabular}{|l} 
effigy bowl, \\
fragment
\end{tabular} & sim. to Crockett & & engraved/appliqued & Erie 2 :: Elmhurst? & $\begin{array}{l}\text { GROG, FINE/ABUNDANT, } \\
\text { OCCASIONAL HEMATITE GRIT }\end{array}$ \\
\hline $23-9$ & $3 \mathrm{HS} 3$ & $\begin{array}{l}\text { effigy handle, } \\
\text { fragment }\end{array}$ & & & modeled/appliqued handle & & GROG, MEDIUM/ABUNDANT \\
\hline $\mathrm{x}$ & unknown & $\begin{array}{l}\text { effigy handle, } \\
\text { fragment }\end{array}$ & & & $\begin{array}{l}\text { modeled/appliqued// } \\
\text { engraved }\end{array}$ & Edgar 3 & $\begin{array}{l}\text { MEDIUM/ABUNDANT, } \\
\text { OCCASIONAL GRIT }\end{array}$ \\
\hline $\mathrm{X}-231$ & $\begin{array}{l}\text { unknown, Hot } \\
\text { Spring County? }\end{array}$ & $\begin{array}{l}\text { effigy handle, } \\
\text { fragment }\end{array}$ & & & modeled/appliqued & & GROG, MEDIUM/ABUNDANT \\
\hline 3-9 & 3 CL83 & effigy seed jar & & Social Hill & appliqued nodes & & SHELL (SOME LEACHED), FINE \\
\hline $9-1$ & $3 \mathrm{HS} 104$ & effigy seed jar & & & modeled/incised & & GROG \& SHELL (LEACHED), FINE \\
\hline $8-1$ & $3 \mathrm{CL} 23$ & $\begin{array}{l}\text { effigy seed jar, } \\
\text { quadruped }\end{array}$ & & Mid-Ouachita & incised/modeled & & GROG, FINE/ABUNDANT \\
\hline $\mathrm{X}-36$ & unknown & $\begin{array}{l}\text { effigy seed jar, } \\
\text { quadruped }\end{array}$ & & & modeled/appliqued/incised & & $\begin{array}{l}\text { GROG \& SHELL (LEACHED), } \\
\text { MEDIUM TO COARSE }\end{array}$ \\
\hline
\end{tabular}

Table 2. Effigy Vessels in the JEC Hodges Collection (Accession 77-1).

somewhat naturalistically in effigy form, we should remember that composite images of supernatural beings may have been intended. As we assemble a corpus of images of Caddo effigy pottery, patterns and repeating characteristics begin to emerge. There are three human effigies in the JEC Hodges Collection; two are bottles with circular Keno Trailed designs and modeled facial features on the bodies and one is a seed jar with modeled/incised facial features and arms and attached legs. The bottles have two faces, one on each side of the bottle body, separated by two vertical line panels (771/1-50) or swirled line panels (77-1/21-136) (the latter similar to Keno Trailed var. Grigsby defined by Early 2000:106- 107 at the Helm site). Similar bottles from sites in Garland and Hot Spring counties can also be seen in the HSU Museum collection, Gilcrease Lemley collection, and several private collections, based on photograph files at the ARAS/HSU Research Station 

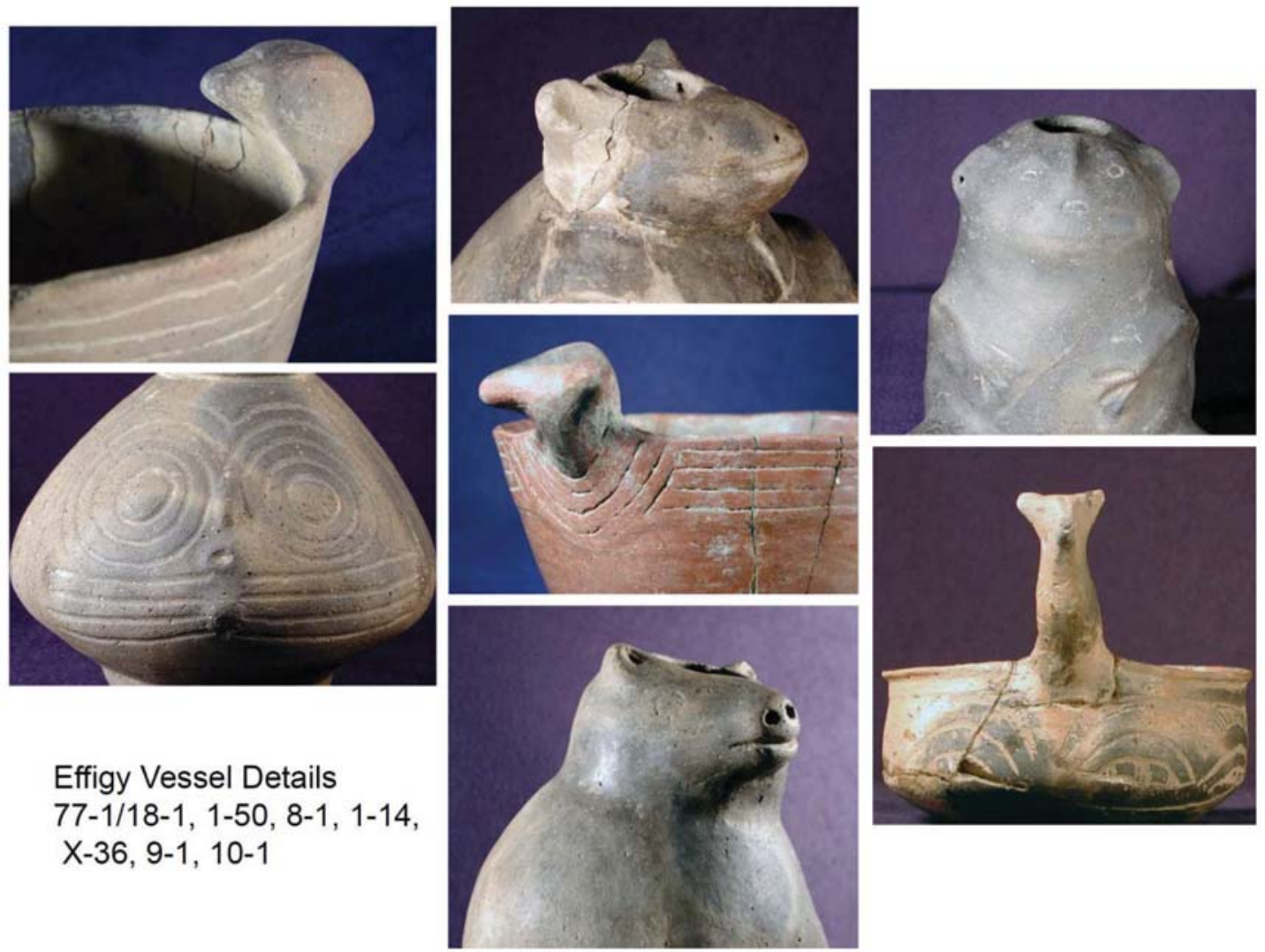

Figure 4. Details of effigy vessels showing modeling of animal and human heads.

(Gilcrease Museum has images of some Caddo pottery in their online collections, https://collections.gilcrease. org/). The human effigy seed jar (77-1/9-1) was found by Richard Reid after the Hodgeses had dug several graves at 3HS104, and its association was unclear (the Hodges catalog entry notes “can't tell where one grave ends and others begin"). This vessel is similar to one illustrated by Moore (1908:Fig. 16-17) from a grave near Menard in Arkansas County. A third type of human effigy bottle, with head and body created from Keno Trailed or Bailey Engraved circular designs on the neck and body of the vessel respectively, was sketched by Huddleston from a grave at 3CL81(Phillips photo 3895?) but is not present in the JEC Hodges Collection; this effigy style is represented in Gilcrease Lemley collection examples from Saline County.

One bowl (77-1/18-1) and a head fragment from another $(77-1 / \mathrm{X})$ can be identified as bird or duck effigies. Similar vessels, with bird heads facing into or away from the bowl, several incised or engraved lines with or without ticking below the rims, and engraved crosshatched or excised areas emphasizing eyes and bills, were found at Poole (3GA3, Wood 1981:Fig. 11) and are well-represented in the ARAS/HSU station photograph files from sites in Clark and Hot Spring counties (and elsewhere in the Caddo Area; see Perttula and Selden 2015). Other examples, such as vessel 771/14-20, have stylized heads that cannot be readily identified as bird or animal. Three bowls (77-1/5-23, 1421, and 21-69) have flanges around the rims that form wings or fins (or carapaces?) and tails of birds or fish (or turtles?). Lines were incised on the top surfaces of the flanges. A head is intact on only one of these effigies. Similar examples are known from sites in Clark, Hot Spring, and Garland counties (including one from Adair, 3GA1, illustrated in Suhm and Jelks 1962:Plate 53E; see also DeMaio 2013). A related form has wings or fins set vertically on the sides of the bowl (vessel 77-1/X-58 and rim sherd 77-1/34). A drawing in the Hodges catalog shows a similar bowl with bird head and describes it as a turkey effigy (Hodges \#1009), but since this vessel has not been identified in the modern collection, it is not clear whether the drawing was a reconstruction or actual vessel drawing. A bowl with modeled/appliqued fins, head, and tail (vessel 77-1/X-32) appears to represent a fish when viewed from the top. This form is more 
commonly seen in Mississippian effigy pottery from eastern Arkansas (House 2003; Mainfort 2008; Phillips et al. 1951).

Bowls with attached heads and tail tabs on either side of the rim depict other animals as well. Vessels 77-1/1-14 and 21-72 are similar in their stylized animal heads. The rattle head of the 21-72 bowl may be a technological feature (to keep the applique handle intact during firing) or may have been important to its use. On vessel 77-1/10-1, a long-necked animal with snout and ears may represent a deer; effigy handle/tab fragments 23-9 and X-231 may also portray deer. The long-necked animal on bowl 77-1/X-34 looks like a frog. A single bowl with quadrupedal animal represented on one tab handle and the effigy broken off the other (vessel 77-1/9-24) is an example of the "tail-riding effigy bowl" form described by Phillips, Ford, and Griffin (1951:168-169); this form is well-represented in the East Texas corpus (Perttula and Selden 2015). Two seed jars (77-1/X-36, 8-1) with modeled facial features and attached legs and tails are thought to represent bears (see also Mainfort 2008:94). A heavilyreconstructed bottle of uncertain authenticity reportedly from a Montgomery County site (vessel 77-1/32-1) has an animal head, fanged/toothed mouth, long body with four legs, and tail. It may depict a bear but could represent a composite supernatural cat-serpent/Great Serpent/Underwater Panther/piasa often portrayed in Mississippian art (House 2003; Lankford 2004; Reilly 2004). The effigy seed jar 77-1/3-9 (from 3CL83) has nodes at the rim forming stylized facial features; similarly stylized features can be seen on an effigy seed jar from Garland County in the Gilcrease Lemley collection.

Two effigy bottles (77-1/X-186 and X-187) can be described as turtles, perhaps snapping turtles with long necks, ridges or knobs and incised or engraved semi-circular designs on bodies, and tails. Bottle $77-1 / \mathrm{X}-186$ has four legs while X-187 has a convex base. Related to these is the Garland Engraved effigy container, vessel 77-1/10-3 from 3HS105. While it does not include a modeled head or other appendages, this vessel may be a whole vessel effigy turtle. Similar small containers are found in the HSU Museum and Gilcrease Lemley collections (from Clark, Garland, and Pike county sites; Suhm and Jelks 1962:Plate 23K-K'). Jim Rees (personal communication, 2016) is currently examining form and function of this vessel category in a separate study. Although their authenticity is unknown, examples pictured from private collections (e.g., Bonds 2007:197,210) appear to provide engraved design links between the container form and quadruped turtle effigies.
An oval Friendship Engraved var. Meador bowl (77-1/9-5) has appliqued handles at either end that may represent stylized animal heads; the vessel itself has a shape described as similar to a "gondola" in the Hodges catalog. There are several other vessels in the JEC Hodges Collection with handles or unusual shapes that could also be effigies (e.g., peaked bowls, triangular or elongated bowls, bowls with rattle knob handles), but these have not been defined as effigies for this study.

\section{Conclusions}

This article presents detailed documentation of 31 effigy vessels or vessel fragments from the JEC Hodges Collection. For the pieces with known site or county location based on notes from Thomas and Charlotte Hodges or from Vere Huddleston, the majority (20 of 23 or 87 percent) come from Caddo sites in the Middle Ouachita region of Clark and Hot Spring counties. Two vessels came from a site in the Little Missouri River region, and one vessel reportedly came from a site in the Ouachita Mountains region.

While description and publication of information about old collections is important and necessary work, documenting these effigy vessels in their archeological and cultural contexts is even more significant. Where there is sufficient detail left by the amateur excavations from the 1930s-1940s, we know that these effigy vessels were taken from mortuary contexts rather than deposited in habitation refuse. Grave lot information provides important information for interpretations about temporal and stylistic changes, function, and iconography.

American Indians living in the Midwest and Southeast shared a view of the universe made up of an Above World of the sky and stars, sun, and moon, the Middle World of earth and humankind, and a Beneath World with water and underwater creatures. Many of the effigy vessels in the JEC Hodges Collection represent turtles, frogs, fish, ducks or other birds, deer, bears, and humans. Particular interest seems to have been given to animals that could transition between worlds; ducks move between water and sky while snapping turtles live in water but can walk on land. The Spanish missionary Fray Isidro Felix de Espinosa described seeing chests or baskets in Hasinai Caddo temples containing wooden vessels shaped with heads and tails of ducks and alligators or lizards (Carter 1995:121; Swanton 1996:155). Caddo effigy vessels made in pottery and from wood may have been comparable or related in function or imagery (Townsend and Walker 2004:240, 244). A side-by-side photograph of a carved wooden duck head from the East Place and a ceramic 
bird head fragment (77-1/1-11 and X; Trubitt and Evans 2015:Fig. 6) shows this similarity (see also wooden duck head effigy adorno from Spiro; Sievert 2011:Fig. 4.38). While images of several of these vessels have appeared in publications before (e.g., Suhm and Jelks 1962), this work expands the corpus of Caddo effigy pottery. Comparisons can be made with effigy pottery from other regions within the Caddo Area (e.g., Harrington 1920; Perttula and Selden 2015). Further research and comparisons between more representational effigy pottery and similar but more stylized decorations on other Caddo pottery may be fruitful.

For example, Keno Trailed or Bailey Engraved bottles with circular or semicircular patterns on vessel bodies may be stylized forms linked to the human effigy bottles (such as 77-1/1-50 and 21-136). A filleted appliqued strip or engraved ticked line around the rim of a bowl may stand in for the wing/fin/carapace flanges on effigy bowls. Designs can be analyzed and compared across multiple media (pottery, shell, copper, and stone) as a way to examine interactions and the movements of objects, influence, and people between the Caddo Area and the Mississippian Southeast in the past.

\section{Acknowledgements}

The Joint Educational Consortium's Hodges Collection is curated at Henderson State University in Arkadelphia, Arkansas. The effigy pottery was documented and photographed between 2000 and 2016 at the Arkansas Archeological Survey's HSU Research Station by Tony Caver, Florence Davis, Jeffrey Gaskin, Mary Ann Goodman, Vanessa Hanvey, Katie Leslie, Emily Miller, Judy Thye, and Kate Wright, under the supervision of Mary Beth Trubitt. JEC Hodges Collection documentation was funded in part by a 2006 grant from the Ross Foundation. A preliminary version of this article was created as part of a conference presentation in the "Exploring the Edges of the Caddo World: The Mississippian World as Viewed from the Caddo Archaeological Area" symposium organized by Duncan P. McKinnon and Amanda L. Regnier, at the 2016 Southeastern Archaeological Conference in Athens, Georgia.

\section{References Cited}

Bonds, Jack (editor)

2007 The Kent and Jonnie Westbrook Collection. Collectors Series Volume 1, Grove Hill Publishing, Leonard, Texas.
Carter, Cecile Elkins

1995 Caddo Indians: Where We Come From. University of Oklahoma Press, Norman.

DeMaio, Joanne

2013 The Adair Site: Ouachita River Valley Relations through Ceramic Analysis. M.A. thesis, Department of Anthropology, University of Arkansas, Fayetteville.

Dowd, Elsbeth Linn

2011 Amphibian and Reptilian Imagery in Caddo Art. Southeastern Archaeology 30(1):79-95.

Early, Ann M.

1986 Dr. Thomas L. Hodges and His Contribution to Arkansas Archeology. The Arkansas Archeologist 23-24:1-9.

2000 Ceramics. In Data Recovery at the Helm Site, 3HS449, Hot Spring County, Arkansas, by Robert H. Lafferty III, Ann Early, Michael C. Sierzchula, H. Cassandra Hill, Gina S. Powell and Neal H. Lopinot, Linda Scott Cummings, Susan L. Scott, Samuel K. Nash, and Timothy K. Perttula, pp. 69-121. MCRA Report 2000-1 (submitted to the Arkansas Highway and Transportation Department), Mid-Continental Research Associates, Lowell, Arkansas.

Early, Ann M. (editor)

1993 Caddoan Saltmakers in the Ouachita Valley: The Hardman Site. Research Series No. 43, Arkansas Archeological Survey, Fayetteville.

Gadus, Eloise Frances

2013 Twisted Serpents and Fierce Birds: Structural Variation in Caddo Engraved Ceramic Bottle Motifs. Bulletin of the Texas Archeological Society 84:213-245.

Girard, Jeffrey S., Timothy K. Perttula, and Mary Beth Trubitt

2014 Caddo Connections: Cultural Interactions within and beyond the Caddo World. Rowman \& Littlefield, Lanham, Maryland.

Harrington, M. R.

1920 Certain Caddo Sites in Arkansas. Museum of the American Indian. Heye Foundation, New York. 
Hodges, T. L., and Mrs. [Charlotte] Hodges

1945 Suggestion for Identification of Certain MidOuachita Pottery as Cahinnio Caddo. Bulletin of the Texas Archeological and Paleontological Society 16:98-116.

House, John H.

2003 Gifts of the Great River: Arkansas Effigy Pottery from the Edwin Curtiss Collection. Peabody Museum Press, Harvard University, Cambridge, Massachusetts.

Huddleston, V. L.

1943 Indians in Clark County. Arkansas Historical Quarterly 2(2):110-115.

Knight, Vernon James, Jr.

2013 Iconographic Method in New World Prehistory. Cambridge University Press, Cambridge, United Kingdom.

Lankford, George E.

2004 World on a String: Some Cosmological Components of the Southeastern Ceremonial Complex. In Hero, Hawk, and Open Hand: American Indian Art of the Ancient Midwest and South, edited by Richard F. Townsend, pp. 207217. Art Institute of Chicago and Yale University Press, New Haven.

Mainfort, Robert C., Jr.

2008 Sam Dellinger: Raiders of the Lost Arkansas. University of Arkansas Press, Fayetteville.

McKinnon, Duncan P.

2015 Zoomorphic Effigy Pendants: An Examination of Style, Medium, and Distribution in the Caddo Area. Southeastern Archaeology 34(2):116-135.

Moore, Clarence B.

1908 Certain Mounds of Arkansas and of Mississippi, Part I, Mounds and Cemeteries of the Lower Arkansas River. Journal of the Academy of Natural Sciences of Philadelphia, 2nd Ser., Vol. XIII.

Perttula, Timothy K., and Robert Z. Selden, Jr. 2015 Effigy Vessel Documentation, Caddo Collections at the Texas Archeological Research Laboratory at The University of Texas at Austin. Special Publication No. 40, Friends of Northeast Texas Archaeology, Austin.
Perttula, Timothy K., Mary Beth Trubitt, and Jeffrey S. Girard

2011 The Use of Shell-Tempered Pottery in the Caddo Area of the Southeastern United States. Southeastern Archaeology 30(2):242-267.

Phillips, Philip, and James A. Brown

1978, 1984 Pre-Columbian Shell Engravings from the Craig Mound at Spiro, Oklahoma. Paperback edition, Parts 1 and 2. Peabody Museum Press, Peabody Museum of Archaeology and Ethnology, Harvard University, Cambridge, Massachusetts.

Phillips, Philip, James A. Ford, and James B. Griffin

1951 Archaeological Survey in the Lower Mississippi Alluvial Valley, 1940-1947. Papers of the Peabody Museum of American Archaeology and Ethnology, Vol. XXV, Harvard University, Cambridge, Massachusetts [1968 reprint, Kraus Reprint Corp., New York].

Reilly, F. Kent, III

2004 People of Earth, People of Sky: Visualizing the Sacred in Native American Art of the Mississippian Period. In Hero, Hawk, and Open Hand: American Indian Art of the Ancient Midwest and South, edited by Richard F. Townsend, pp. 125-137. Art Institute of Chicago and Yale University Press, New Haven.

Schambach, Frank F., and John E. Miller 1984 A Description and Analysis of the Ceramics. In Cedar Grove: An Interdisciplinary Investigation of a Late Caddo Farmstead in the Red River Valley, edited by Neal L. Trubowitz, pp. 109-170. Research Series No. 23, Arkansas Archeological Survey, Fayetteville.

Sievert, April K., with J. Daniel Rogers and Javier Urcid 2011 Artifacts from the Craig Mound at Spiro, Oklahoma. Smithsonian Contributions to Anthropology No. 49, Smithsonian Institution Scholarly Press, Washington, D.C.

Suhm, Dee Ann, and Edward B. Jelks, editors

1962 Handbook of Texas Archeology: Type Descriptions. Special Publication No. 1, Texas Archeological Society, and Bulletin No. 4, Texas Memorial Museum, Austin. 18

Swanton, John R.

1996 Source Material on the History and Ethnology of the Caddo Indians. University of Oklahoma Press, Norman. 
Townsend, Richard F., and Chester P. Walker

2004 The Ancient Art of Caddo Ceramics. In Hero, Hawk, and Open Hand: American Indian Art of the Ancient Midwest and South, edited by Richard F. Townsend, pp. 231-245. Art Institute of Chicago and Yale University Press, New Haven.

Trubitt, Mary Beth

2016 The Other "Star" Bottle from Menard. Field Notes: Newsletter of the Arkansas Archeological Society 391:6-7.

Trubitt, Mary Beth, and Linda Evans

2015 Revisiting a Historic Manuscript: Vere Huddleston's Report on East Place (3CL21) Excavations. Caddo Archeology Journal 25:73144.
Walker, Leslie

2014 Liminal River: Art, Agency and Cultural Transformation Along the Protohistoric Arkansas River. Ph.D. dissertation, Department of Anthropology, University of Arkansas, Fayetteville.

Wood, W. Raymond, with Ann M. Early

1981 The Poole Site, 3GA3. The Arkansas Archeologist 22:7-64. 


\title{
Effigy Pottery in the Joint Educational Consortium's Hodges Collection
}

\author{
Appendix \\ Effigy Vessel Documentation, JEC Hodges Collection
}


JEC Hodges Collection, 77-1 Effigy Vessels

Vessel Form

ARAS/HSU Digital Photo No.

Type

Decoration

Rim :: Body

Paste

Temper

Color, Core

Color, Exterior

Color, Interior

Vessel Overall Height $(\mathrm{cm})$

Vessel Overall Weight (g)

Vessel Maximum Diameter $(\mathrm{cm})$

Volume (liters)

Use/Wear/Condition

Shape/Description

Lip Treatment/Shape/Angle

Orifice Diameter $(\mathrm{cm})$

Rim/Neck Height (cm)

Rim/Neck Thickness (cm)

Rim/Neck Shape/Angle

Rim/Neck Surface/Decorative Treatment Body Maximum Diameter (cm)

Body Height $(\mathrm{cm})$

Body Thickness (cm)

Body Surface/Decorative Treatment

Body Shape

Base Shape/Curvature

Base Diameter $(\mathrm{cm})$

Base Height

Base Surface/Decorative Treatment

Appendages/Handles

Notes
1-14; 2694 / 3CL21

effigy bowl

1206

East Incised

red slipped/incised/modeled

Bates 15 or Barrington 5 :: plain

SOFT, GRANULAR, COMPACT

GROG, FINE TO MEDIUM

RED (2.5YR4/8)

RED (2.5YR4/8)

9.7

326.0

VESSEL RECONSTRUCTED WITH GLUE AND BADLY PLASTERED (TAIL TAB), NO APPARENT WEAR BUT SLIP WORN OFF INTERIOR OF HEAD

SMALL EFFIGY VESSEL, SHALLOW BOWL WITH ANIMAL HEAD (FOX?) RIDING ON RIM FACING UP; ABRUPT BREAK BETWEEN BASE AND BODY

DIRECT, FLATTENED

13.9

2.6

0.6

STRAIGHT/OUTSLANTED

SMOOTHED \& BURNISHED \& SLIPPED; RED SLIPPED INT AND EXT; 4 INCISED HORIZONTAL LINES, PARTLY SMOOTHED OVER (0.1CM WIDE, 0.5-0.6CM APART), NOT OVERHANGING, 5 LINES UNDER HEAD APPENDAGE

11.6

4.8

0.6

SMOOTHED \& BURNISHED \& SLIPPED

CONICAL

CIRCULAR/FLAT

8.8

ANIMAL HEAD (FACING IN) ON RIM; TAIL LUG HAS BEEN RECONSTRUCTED FROM PLASTER

Huddleston Grave B, 11/21/1942 (with 1-2, 1-3, and 2 other effigies given away by Huddleston), East phase; previous illustration Trubitt \& Evans 2015: Fig. 9 \& Appendix 
JEC Hodges Collection, 77-1 Effigy Vessels

\section{Vessel Form}

ARAS/HSU Digital Photo No.

Type

Decoration

Rim :: Body

Paste

Temper

Color, Core

Color, Exterior

Color, Interior

Vessel Overall Height (cm)

Vessel Overall Weight (g)

Vessel Maximum Diameter $(\mathrm{cm})$

Volume (liters)

Use/Wear/Condition

Shape/Description

Lip Treatment/Shape/Angle

Orifice Diameter (cm)

Rim/Neck Height (cm)

Rim/Neck Thickness (cm)

Rim/Neck Shape/Angle

Rim/Neck Surface/Decorative Treatment Body Maximum Diameter $(\mathrm{cm})$

Body Height $(\mathrm{cm})$

Body Thickness (cm)

Body Surface/Decorative Treatment

Body Shape

Base Shape/Curvature

Base Diameter $(\mathrm{cm})$

Base Height

Base Surface/Decorative Treatment

Appendages/Handles

Notes
1-50; 1372 (Huddleston 208) / 3CL21

effigy bottle, pedestalled

427

Keno Trailed

incised/trailed/modeled/appliqued

plain :: Baker 27?

SOFT, COMPACT

SHELL (LEACHED), MEDIUM TO COARSE/ABUNDANT

LIGHT GRAY (10YR8/1)

GRAY-SOME FIRECLOUDING (10YR4/2)

GRAY (10YR4/1)

14.7

412.2

SOME LIP DAMAGE, PROBABLY POST-DEPOSITIONAL

BOTTLE, HUMAN FACE EFFIGY, PEDESTAL

FLARED (LIP HEIGHT 1.1CM)

6.2

4.2

0.5

SPOOLBULBOUS

SMOOTHED

13.7

9.7

SMOOTHED / WIDE LINE INCISING/TRAILING AND SURFACE MODELING (NODES), 2 HUMAN FACE EFFIGIES ON 2 PANELS WITH VERTICAL LINES IN BETWEEN

LOW-WAIST

CIRCULAR/FLAT/PEDESTAL

7.0

0.8

Huddleston Grave 3, 4/29-5/5/1939 (with 1-13, 1-32, 1-34, 1-41?), late Social Hill to Deceiper phase;

Huddleston sketch in notebook; Phillips photo 3857; previous illustrations Suhm \& Jelks 1962: Plate 44K; Trubitt \& Evans 2015: Fig. 8 \& Appendix 
JEC Hodges Collection, 77-1

Effigy Vessels

Vessel Form

ARAS/HSU Digital Photo No.

Type

Decoration

Rim :: Body

Paste

Temper

Color, Core

Color, Exterior

Color, Interior

Vessel Overall Height $(\mathrm{cm})$

Vessel Overall Weight (g)

Vessel Maximum Diameter $(\mathrm{cm})$

Volume (liters)

Use/Wear/Condition

Shape/Description

Lip Treatment/Shape/Angle

Orifice Diameter $(\mathrm{cm})$

Rim/Neck Height $(\mathrm{cm})$

Rim/Neck Thickness (cm)

Rim/Neck Shape/Angle

Rim/Neck Surface/Decorative Treatment Body Maximum Diameter $(\mathrm{cm})$

Body Height $(\mathrm{cm})$

Body Thickness (cm)

Body Surface/Decorative Treatment

Body Shape

Base Shape/Curvature

Base Diameter $(\mathrm{cm})$

Base Height

Base Surface/Decorative Treatment

Appendages/Handles

Notes
3-9; 2845 / 3CL83

effigy seed jar

3748

appliqued nodes

MEDIUM-HARD, FINE, SILTY, COMPACT

SHELL (SOME LEACHED), FINE

BROWN (10YR5/3)

VERY DARK GRAYISH BROWN (10YR3/2), REDDISH BROWN (5YR5/4), REDDISH YELLOW (7.5YR6/6)

17.0

939.0

VESSEL RECONSTRUCTED WITH GLUE; LARGE CRACK IN SIDE DUE TO VESSEL WARPING; SMALL PROBE HOLE UNDER LEFT "EAR"; LIGHT TO MODERATE WEAR AROUND RIM AND BODY, HEAVY WEAR ON BASE

EFFIGY SEED JAR WITH 4 APPLIQUE NODES ON RIM FOR FACIAL FEATURES, FLAT

INCURVED LIP, GLOBULAR BODY, AND FLAT BASE

INCURVED, FLAT

4.1

4.0

0.6

APPLIQUE; 4 APPLIQUED NODES ON RIM (2 VERTICAL IN FRONT AND 2 OPPOSING EACH OTHER ON EITHER SIDE) FORM FACE

18.5

13.0

0.6

SMOOTHED

GLOBULAR

FLAT

7.0

4 APPLIQUE NODES ON RIM FORMING FACIAL EFFIGY

Associated Funerary Object; Huddleston Grave G3, 11/20/1943, (with 3-10, 3-15, 3-17), Social Hill phase; described by Huddleston as owl effigy 
JEC Hodges Collection, 77-1 Effigy Vessels

\section{Vessel Form}

ARAS/HSU Digital Photo No.

Type

Decoration

Rim :: Body

Paste

Temper

Color, Core

Color, Exterior

Color, Interior

Vessel Overall Height $(\mathrm{cm})$

Vessel Overall Weight (g)

Vessel Maximum Diameter $(\mathrm{cm})$

Volume (liters)

Use/Wear/Condition

Shape/Description

Lip Treatment/Shape/Angle

Orifice Diameter $(\mathrm{cm})$

Rim/Neck Height (cm)

Rim/Neck Thickness (cm)

Rim/Neck Shape/Angle

Rim/Neck Surface/Decorative Treatment Body Maximum Diameter $(\mathrm{cm})$

Body Height $(\mathrm{cm})$

Body Thickness (cm)

Body Surface/Decorative Treatment

Body Shape

Base Shape/Curvature

Base Diameter $(\mathrm{cm})$

Base Height

Base Surface/Decorative Treatment

Appendages/Handles

Notes
14-20; 1340 (Huddleston 44) / 3CL81

effigy bowl

3739

appliqued handles

HARD, FINE, SILTY, COMPACT

GROG \& SHELL (LEACHED), ABUNDANT

VERY DARK GRAYISH BROWN (10YR3/2)

VERY DARK GRAYISH BROWN (10YR3/2), BLACK (10YR2/1), BROWN (10YR5/3)

VERY DARK GRAYISH BROWN (10YR3/2), BROWN (10YR5/3), GRAYISH BROWN (10YR5/2)

13.5

547.0

VESSEL RECONSTRUCTED WITH GLUE, SEVERAL FRAGMENTS MISSING FROM LOWER BODY/BASE; BODY AND BASE MODERATELY WORN

SIMPLE BOWL; TWO APPLIQUED HANDLES/NODES, ABSTRACT ANIMAL/BIRD HEAD/TAIL DIRECT, FLATTENED

24.5

20.4

13.5

0.5

SMOOTHED \& BURNISHED

CONICAL, STRAIGHT-SIDED V-SHAPE BOWL

FLATTENED

11.7

2 APPLIQUE NODES FOR EFFIGY HEAD AND TAIL

Huddleston Grave B-1, 5/14/1938 (with 1-1303 in HSU Museum Collection), Mid-Ouachita phase; Phillips photo 3904 (prev. id'd as 3CL40, Freeman, but sketch in Huddleston notes fits Stanford description) 
JEC Hodges Collection, 77-1 Effigy Vessels

Vessel Form

ARAS/HSU Digital Photo No.

Type

Decoration

Rim :: Body

Paste

Temper

Color, Core

Color, Exterior

Color, Interior

Vessel Overall Height $(\mathrm{cm})$

Vessel Overall Weight (g)

Vessel Maximum Diameter $(\mathrm{cm})$

Volume (liters)

Use/Wear/Condition

Shape/Description

Lip Treatment/Shape/Angle

Orifice Diameter $(\mathrm{cm})$

Rim/Neck Height $(\mathrm{cm})$

Rim/Neck Thickness (cm)

Rim/Neck Shape/Angle

Rim/Neck Surface/Decorative Treatment Body Maximum Diameter (cm)

Body Height $(\mathrm{cm})$

Body Thickness (cm)

Body Surface/Decorative Treatment

Body Shape

Base Shape/Curvature

Base Diameter $(\mathrm{cm})$

Base Height

Base Surface/Decorative Treatment

Appendages/Handles

Notes
$5-23 ; 2399 / 3$ CL81

effigy bowl

3963

Means Engraved

engraved/appliqued flange/handles

Elgin 1 :: plain

HARD, FINE, SILTY, COMPACT

SHELL (SOME LEACHED), FINE/ABUNDANT

VERY DARY GRAY (10YR3/1), DARK GRAY (10YR4/1)

LIGHT YELLOWISH BROWN (10YR6/4), DARK GRAYISH BROWN (10YR4/2), BLACK (10YR2/1)

BLACK (10YR2/1), VERY DARK GRAY (10YR3/1), DARK GRAY (10YR4/1)

10.7

428.0

VESSEL RECONSTRUCTED WITH GLUE. VESSEL IS WORN SLIGHTLY TO MODERATELY ALL AROUND.

SIMPLE BOWL WITH EFFIGY HEAD BROKEN OFF AND FLANGE AROUND RIM (BIRD?)

DIRECT, FLATTENED

16.1

3.0

0.4

ENGRAVED WITH APPLIQUE; SINGLE TICKED LINE BELOW LIP; APPLIQUE FLANGE BELOW TICKED LINE (BIRD WINGS WITH PRONGED HEAD/TAIL?)

18.8

7.7

0.4

SMOOTHED \& LIGHTLY BURNISHED

CONVEX, ROUNDED

CONVEX, SLIGHTLY ROUNDED

APPLIQUE FLANGE, BIRD/FOWL EFFIGY? (WINGS WITH PRONGED HEAD/TAIL)

Huddleston Grave B-26?, 1/4/1941 (with 5-5, 5-29), Social Hill phase; described by Huddleston as turtle effigy 
JEC Hodges Collection, 77-1 Effigy Vessels

\section{Vessel Form}

ARAS/HSU Digital Photo No.

Type

Decoration

Rim :: Body

Paste

Temper

Color, Core

Color, Exterior

Color, Interior

Vessel Overall Height $(\mathrm{cm})$

Vessel Overall Weight (g)

Vessel Maximum Diameter (cm)

Volume (liters)

Use/Wear/Condition

Shape/Description

Lip Treatment/Shape/Angle

Orifice Diameter $(\mathrm{cm})$

Rim/Neck Height (cm)

Rim/Neck Thickness (cm)

Rim/Neck Shape/Angle

Rim/Neck Surface/Decorative Treatment Body Maximum Diameter $(\mathrm{cm})$

Body Height $(\mathrm{cm})$

Body Thickness $(\mathrm{cm})$

Body Surface/Decorative Treatment

Body Shape

Base Shape/Curvature

Base Diameter $(\mathrm{cm})$

Base Height

Base Surface/Decorative Treatment

Appendages/Handles

Notes
8-1; 1207 / 3CL23

effigy seed jar, quadruped

1214

incised/modeled

SOFT, COARSE, SOME SAND/PEBBLES

GROG, FINE/ABUNDANT

LIGHT YELLOWISH BROWN (10YR6/4)

DARK GRAY (10YR4/1), VERY PALE BROWN (10YR7/3), REDDISH YELLOW (5YR6/6)

21.0

1194.0

VESSEL WAS HEAVILY RECONSTRUCTED WITH GLUE AND PLASTER; FRONT LEGS BROKEN; NO USE WEAR APPARENT

LARGE BULBOUS EFFIGY SEED JAR WITH 4 LEGS; OPENING ON TOP OF THE HEAD; BEAR?

EFFIGY

ROUNDED

3.3

4.0

0.7

SMOOTHED \& BURNISHED; MODELED HEAD FEATURES (EARS, SNOUT) WITH INCISED EYE CIRCLES, MOUTH LINE, AND 2 PUNCTATES FOR NOSE

15.2

13.6

0.6

SMOOTHED \& BURNISHED / MODELED LEGS ATTACHED TO BASE-FRONT LEGS HAVE BEEN ATTACHED ONTO BODY

GLOBULAR, OFFSET BETWEEN LEGS (SUPPORTS) AND HEAD (OPENING) CONVEX 
JEC Hodges Collection, 77-1

Effigy Vessels

Vessel Form

ARAS/HSU Digital Photo No.

Type

Decoration

Rim :: Body

Paste

Temper

Color, Core

Color, Exterior

Color, Interior

Vessel Overall Height $(\mathrm{cm})$

Vessel Overall Weight (g)

Vessel Maximum Diameter $(\mathrm{cm})$

Volume (liters)

Use/Wear/Condition

Shape/Description

Lip Treatment/Shape/Angle

Orifice Diameter $(\mathrm{cm})$

Rim/Neck Height $(\mathrm{cm})$

Rim/Neck Thickness (cm)

Rim/Neck Shape/Angle

Rim/Neck Surface/Decorative Treatment

Body Maximum Diameter (cm)

Body Height $(\mathrm{cm})$

Body Thickness (cm)

Body Surface/Decorative Treatment

Body Shape

Base Shape/Curvature

Base Diameter $(\mathrm{cm})$

Base Height

Base Surface/Decorative Treatment

Appendages/Handles

Notes
9-1; 140A / 3HS104

effigy seed jar

1233

modeled/incised

HARD, COARSE, COMPACT

GROG \& SHELL (LEACHED), FINE

VERY DARK GRAY (10YR3/1)

21.4

1136.0

VESSEL RECONSTRUCTED WITH GLUE; SURFACE MORE ABRADED ON FRONT OF VESSEL (POSTDEPOSITIONAL?), SOME ABRASION ON BASE AND BASE OF LEGS (USE WEAR?); NICK ON ONE EAR, HOLE IN OTHER.

HUMAN EFFIGY SEED JAR, SMALL OPENING ON TOP OF HEAD, BULBOUS LEGS, SMALL FACIAL FEATURES

ROUNDED, INCURVED

4.0

SMOOTHED \& BURNISHED

22.3

21.4

0.6

SMOOTHED \& BURNISHED / EFFIGY MODELING TO CREATE FACE (EARS, NOSE) AND ARMS ON BODY-INCISED LINES TO FORM EYES AND MOUTH, FINGERS

EFFIGY, SEMI-CYLINDRICAL BODY, INCURVING NEAR TOP TO FORM NECK

BULBOUS LEGS/FEET ARE ATTACHED TO BASE-LOOKS LIKE AT LEAST PARTIALLY HOLLOW RATHER THAN SOLID

Hodges catalog notes "Human effigy: found by Richard Reid ... In grave . . . Skeletal remains destroyed"; previous illustration Suhm \& Jelks 1962: Plate 25B 
JEC Hodges Collection, 77-1

Effigy Vessels

Vessel Form

ARAS/HSU Digital Photo No.

Type

Decoration

Rim :: Body

Paste

Temper

Color, Core

Color, Exterior

Color, Interior

Vessel Overall Height (cm)

Vessel Overall Weight (g)

Vessel Maximum Diameter $(\mathrm{cm})$

Volume (liters)

Use/Wear/Condition

Shape/Description

Lip Treatment/Shape/Angle

Orifice Diameter (cm)

Rim/Neck Height (cm)

Rim/Neck Thickness (cm)

Rim/Neck Shape/Angle

Rim/Neck Surface/Decorative Treatment Body Maximum Diameter (cm)

Body Height $(\mathrm{cm})$

Body Thickness $(\mathrm{cm})$

Body Surface/Decorative Treatment

Body Shape

Base Shape/Curvature

Base Diameter $(\mathrm{cm})$

Base Height

Base Surface/Decorative Treatment

Appendages/Handles

Notes
$9-5 ; 142 / 3 \mathrm{HS} 104$

effigy bowl (?)

K8388

Friendship Engraved var. Meador

engraved/appliqued handles

Elwyn $7::$ plain

HARD, COMPACT, SMOOTH, WITH MICA

SHELL (LEACHED) \& GROG, FINE/ABUNDANT

BLACK (7.5YR2.5/1), LIGHT BROWN (7.5YR6/4), STRONG BROWN (7.5YR5/6)

DARK GRAY (7.5YR4/1), STRONG BROWN (7.5YR5/6)

6.7

402.0

1.1

RECONSTRUCTED WITH PLASTER PATCHES ON BODY / BASE ROUGHENING (USEWEAR?), CHIP ON THE LIP OF VESSEL

OVAL SHAPE TO BOWL (ORIFICE $23.3 \times 13.2 \mathrm{CM}$ ), APPLIQUED HANDLES/NODES MAY BE

ABSTRACTED ANIMAL HEADS

BURNISHED/ROUNDED/EVERTED/0.2CM

23.3

5.0

0.5

STRAIGHT/VERTICAL

BURNISHED; ENGRAVED; ZONES OF CROSS HATCHING, TICKED LINE AT BASE OF RIM 26.0

1.7

5.0

BURNISHED / PLAIN

ELONGATED

UNDISTINGUISHED/CONVEX

BURNISHED

APPLIQUED TABS ON THE ENDS OF BOWL (EFFIGY HEADS?)

Hodges catalog notes "Gondola-like bowl. Effigy. Engraved rim-restored", found with 9-3 and 9-4?, MidOuachita phase; Phillips photo 3541; previous illustration Suhm \& Jelks 1962: Plate 23B 
JEC Hodges Collection, 77-1

Effigy Vessels

Vessel Form

ARAS/HSU Digital Photo No.

Type

Decoration

Rim :: Body

Paste

Temper

Color, Core

Color, Exterior

Color, Interior

Vessel Overall Height (cm)

Vessel Overall Weight ( $\mathrm{g}$ )

Vessel Maximum Diameter (cm)

Volume (liters)

Use/Wear/Condition

Shape/Description

Lip Treatment/Shape/Angle

Orifice Diameter $(\mathrm{cm})$

Rim/Neck Height $(\mathrm{cm})$

Rim/Neck Thickness (cm)

Rim/Neck Shape/Angle

Rim/Neck Surface/Decorative Treatment

Body Maximum Diameter $(\mathrm{cm})$

Body Height $(\mathrm{cm})$

Body Thickness (cm)

Body Surface/Decorative Treatment

Body Shape

Base Shape/Curvature

Base Diameter $(\mathrm{cm})$

Base Height

Base Surface/Decorative Treatment

Appendages/Handles

Notes
9-24; $307 / 3$ HS 104

effigy bowl

N8657

engraved/modeled/appliqued

Erie 4 :: plain

HARD, COMPACT, SMOOTH

GROG

DARK GRAY (10YR4/1)

VERY DARK GRAY (10YR3/1), DARK GRAY (10YR4/1)

VERY DARK GRAY (10YR3/1)

11.3

421.0

0.9

VESSEL RECONSTRUCTED, MISSING SHERDS FROM BASE AND RIM, EFFIGY BROKEN ON ONE HANDLE, MISSING FROM OTHER

"TAIL-RIDER" EFFIGY BOWL WITH HANDLES (ANIMAL ON ONE)

BEVELED/SLIGHTLY EVERTED/0.3CM

17.2

3.0

0.5

STRAIGHT/OUTSLANTED

BURNISHED; FOUR HORIZONTAL ENGRAVED LINES 0.6-0.8CM APART BELOW LIP

22.2

6.0

0.5

BURNISHED / PLAIN

CONVEX

UNDISTINGUISHED/FLAT

BURNISHED

APPLIQUED ANIMAL ON ONE TAB, FOUR LEGS AND TAIL, HEAD BROKEN OFF/OTHER TAB IS WIDE AND FLAT, BROKEN WITH NOTCHES ON IT

Hodges catalog notes described as bear effigy, restored; Phillips photo 3712; previous citation by Phillips Ford \& Griffin 1951:169 
JEC Hodges Collection, 77-1

Effigy Vessels

Vessel Form

ARAS/HSU Digital Photo No.

Type

Decoration

Rim :: Body

Paste

Temper

Color, Core

Color, Exterior

Color, Interior

Vessel Overall Height $(\mathrm{cm})$

Vessel Overall Weight (g)

Vessel Maximum Diameter $(\mathrm{cm})$

Volume (liters)

\section{Use/Wear/Condition \\ Shape/Description \\ Lip Treatment/Shape/Angle \\ Orifice Diameter $(\mathrm{cm})$ \\ Rim/Neck Height (cm) \\ Rim/Neck Thickness (cm) \\ Rim/Neck Shape/Angle}

Rim/Neck Surface/Decorative Treatment

Body Maximum Diameter $(\mathrm{cm})$

Body Height $(\mathrm{cm})$

Body Thickness (cm)

Body Surface/Decorative Treatment

Body Shape

Base Shape/Curvature

Base Diameter (cm)

Base Height

Base Surface/Decorative Treatment

Appendages/Handles

Notes
10-1; 694 / 3HS105

effigy bowl

1238

Garland Engraved

engraved/modeled/appliqued

Erie 12 :: Elmira 33 or 36 ?

MEDIUM SOFT, COARSE, COMPACT, OCCASIONAL PEBBLES

GROG \& SHELL (LEACHED), MEDIUM/ABUNDANT

VERY DARK GRAY (10YR3/1), LIGHT YELLOWISH BROWN (10YR6/4), REDDISH YELLOW (7.5YR6/6)

VERY DARK GRAY (10YR3/1), REDDISH YELLOW (7.5YR6/6)

11.2

222.0

SURFACE ABRASION ON ONE SIDE; VESSEL RECONSTRUCTED WITH GLUE, SHERD MISSING FROM BASE AND TAIL LUG MISSING

SMALL SHALLOW CARINATED BOWL WITH APPENDAGE (DEER?), MISSING TAIL

THINNED/ROUNDED/FLARED

13.0

1.2

0.5

CARINATED

SMOOTHED \& BURNISHED; ENGRAVED HORIZONTAL LINE JUST UNDER FLARED LIP 0.5$0.7 \mathrm{CM}$ ABOVE BODY DESIGN

13.0

5.0

.7

SMOOTHED \& BURNISHED / ENGRAVED CURVILINEAR LINES AND CROSSHATCHED AREASWHITE PIGMENT IN ENGRAVED LINES (TRACE)-LINES ARE WIDE AND IRREGULAR

SHALLOW ROUNDED BOWL WITH FLAT BASE (LOW CARINATION)

CIRCULAR/FLAT

DEER HEAD ENGRAVED WITH MOUTH, EYES AND LINES ALONG SIDE AND BACK OF NECKLOOKS LIKE TAIL APPENDAGE BROKEN OFF

Hodges catalog notes describe as "faun" effigy; Mid-Ouachita phase 
JEC Hodges Collection, 77-1

Effigy Vessels

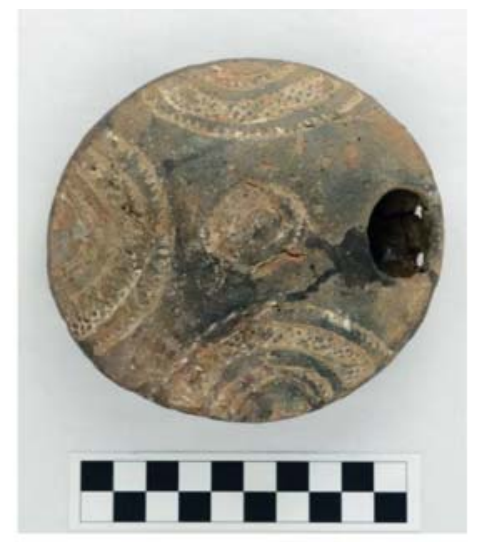

Vessel Form

ARAS/HSU Digital Photo No.

10-3; 692 / 3HS105

Type

Decoration

Rim :: Body

Paste

Temper

Color, Core

Color, Exterior

container, effigy (?)

N14519

Garland Engraved

engraved

:: Elmira 30?

HARD, SMOOTH, CRUMBLY

SHELL (LEACHED) \& GROG, FINE/SPARSE

LIGHT REDDISH BROWN (5YR6/3), DARK REDDISH BROWN (5YR3/2)

Color, Interior

Vessel Overall Height $(\mathrm{cm})$

Vessel Overall Weight (g)

Vessel Maximum Diameter $(\mathrm{cm})$

Volume (liters)

Use/Wear/Condition

Shape/Description

Lip Treatment/Shape/Angle

Orifice Diameter $(\mathrm{cm})$

Rim/Neck Height (cm)

Rim/Neck Thickness (cm)

Rim/Neck Shape/Angle

Rim/Neck Surface/Decorative Treatment Body Maximum Diameter $(\mathrm{cm})$

11.4

Body Height $(\mathrm{cm})$

3.0

Body Thickness (cm)

Body Surface/Decorative Treatment

Body Shape

Base Shape/Curvature

Base Diameter $(\mathrm{cm})$

Base Height

Base Surface/Decorative Treatment

Appendages/Handles

Notes

Hodges catalog notes "Very unusual pendant - container", found in vessel 10-18, Mid-Ouachita phase 
JEC Hodges Collection, 77-1

Effigy Vessels

Vessel Form

ARAS/HSU Digital Photo No.

Type

Decoration

Rim :: Body

Paste

Temper

Color, Core

Color, Exterior

Color, Interior

Vessel Overall Height $(\mathrm{cm})$

Vessel Overall Weight (g)

Vessel Maximum Diameter $(\mathrm{cm})$

Volume (liters)

Use/Wear/Condition

Shape/Description

Lip Treatment/Shape/Angle

Orifice Diameter $(\mathrm{cm})$

Rim/Neck Height $(\mathrm{cm})$

Rim/Neck Thickness (cm)

Rim/Neck Shape/Angle

Rim/Neck Surface/Decorative Treatment Body Maximum Diameter (cm)

Body Height $(\mathrm{cm})$

Body Thickness (cm)

Body Surface/Decorative Treatment

Body Shape

Base Shape/Curvature

Base Diameter (cm)

Base Height

Base Surface/Decorative Treatment

Appendages/Handles

Notes
14-21; 2738 / 3CL40

effigy bowl

3733

appliqued flange/modeled

HARD, FINE, SILTY, COMPACT

GROG \& SHELL (LEACHED), FINE/ABUNDANT

LIGHT BROWNISH GRAY (10YR6/2), VERY PALE BROWN (10YR7/3), DARK GRAYISH BROWN $(10 \mathrm{YR} 4 / 2)$

LIGHT BROWNISH GRAY (10YR6/2), YELLOWISH BROWN (10YR5/4)

12.0

518.0

RECONSTRUCTION WITH GLUE AND PLASTER PATCHES; SEVERAL CRACKS ALONG BODY AND BASE

EFFIGY BOWL WITH MODELED HEAD (BIRD WITH BEAK?), FLANGE AROUND RIM (WINGS?), TAIL

FLATTENED, FLUSH

17.3

3.4

0.5

SMOOTHED; EFFIGY WITH BIRD HEAD

17.3

8.6

0.7

SMOOTHED / PLAIN WITH EFFIGY APPLIQUE (WINGS AND TAIL OF BIRD)

CONVEX

CIRCULAR/CONVEX

APPLIQUED FLANGES (2 WINGS AND TAIL) WITH INCISED LINES/ENGRAVED CROSSHATCHING ON TOP SURFACE, AND HEAD WITH BEAK OF A BIRD

Huddleston Grave B'X', 12/23/1942 (with 14-11, 14-14, 14-19, 14-35), Mid-Ouachita phase 
JEC Hodges Collection, 77-1

Effigy Vessels

Vessel Form

ARAS/HSU Digital Photo No.

Type

Decoration

Rim :: Body

Paste

Temper

Color, Core

Color, Exterior

Color, Interior

Vessel Overall Height (cm)

Vessel Overall Weight $(\mathrm{g})$

Vessel Maximum Diameter $(\mathrm{cm})$

Volume (liters)

Use/Wear/Condition

Shape/Description

Lip Treatment/Shape/Angle

Orifice Diameter $(\mathrm{cm})$

Rim/Neck Height (cm)

Rim/Neck Thickness (cm)

Rim/Neck Shape/Angle

Rim/Neck Surface/Decorative Treatment Body Maximum Diameter (cm)

Body Height (cm)

Body Thickness $(\mathrm{cm})$

Body Surface/Decorative Treatment

Body Shape

Base Shape/Curvature

Base Diameter $(\mathrm{cm})$

Base Height

Base Surface/Decorative Treatment

Appendages/Handles

Notes
$14-49 ; 152$ / 3CL40

effigy bowl (?)

3811

Means Engraved

engraved/appliqued handles

Elgin 2 :: plain

HARD, FINE, SILTY, COMPACT

SHELL (SOME LEACHED) \& GROG, FINE/SPARSE

REDDISH GRAY (5YR5/2), REDDISH BROWN (5YR5/3-5/4)

YELLOWISH RED (5YR5/6), BLACK (10YR2/1), YELLOWISH BROWN (10YR5/4)

BLACK (10YR2/1), BROWN (10YR5/3), LIGHT YELLOWISH BROWN (10YR6/4)

8.0

288.0

VESSEL MISSING 1 APPLIQUED HANDLE; THIN CRACK ALONG ONE SIDE AND SMALL PROBE HOLE IN BASE; MODERATE TO HEAVY WEAR ON BASE

SIMPLE BOWL (CONTINUOUS PROFILE RIM TO BODY)

DIRECT, FLATTENED

14.6

1.5

0.4

SMOOTHED \& ENGRAVED; 2 TICKED HORIZONTAL LINES ENGRAVED BELOW LIP

14.0

6.5

0.4

SMOOTHED

SUB-GLOBULAR

UNDISTINGUISHED/CONVEX

APPLIQUE HANDLES (ONE BROKEN OFF) ON OPPOSITE SIDES

Hodges catalog notes "Bowl: semi-glob. - 2 lugged. 1 lug missing"; Phillips photo 3536 
JEC Hodges Collection, 77-1

Effigy Vessels

\section{Vessel Form}

ARAS/HSU Digital Photo No.

Type

Decoration

Rim :: Body

Paste

Temper

Color, Core

Color, Exterior

Color, Interior

Vessel Overall Height (cm)

Vessel Overall Weight (g)

Vessel Maximum Diameter (cm)

Volume (liters)

Use/Wear/Condition

Shape/Description

Lip Treatment/Shape/Angle

Orifice Diameter $(\mathrm{cm})$

Rim/Neck Height (cm)

Rim/Neck Thickness (cm)

Rim/Neck Shape/Angle

Rim/Neck Surface/Decorative Treatment Body Maximum Diameter $(\mathrm{cm})$

Body Height $(\mathrm{cm})$

Body Thickness $(\mathrm{cm})$

Body Surface/Decorative Treatment

Body Shape

Base Shape/Curvature

Base Diameter (cm)

Base Height

Base Surface/Decorative Treatment

Appendages/Handles

Notes
18-1; 90 / unknown

effigy bowl

K5241

engraved/appliqued/modeled

Bates 2 :: plain

HARD, COMPACT, SMOOTH

GROG \& SHELL (LEACHED), FINE/SPARSE

BROWN (7.5YR5/3), LIGHT BROWN (7.5YR6/4)

BROWN (7.5YR4/2)

12.0

731.0

1.2

WEAR ON THE BACK OF EFFIGY HEAD

BOWL, MODELED HEAD/BEAK (BIRD) WITH ENGRAVED EYE, FACING TO INTERIOR OF VESSEL

BURNISHED

15.5

3.0

0.5

DRY PASTE INCISED LINES AROUND RIM (BATES 2 RATHER THAN ERIE 3)

21.0

12.0

0.5

BURNISHED / PLAIN

CONICAL/EFFIGY

CONVEX

13.0

EFFIGY HEAD RESEMBLES THAT OF A BIRD, HEAD FACING INWARD/HAS TAIL ON THE OTHER END OF VESSEL; EXCISED AREAS ON EYES AND BEAK

Hodges catalog notes describe as bird effigy; Phillips photo 3575 
JEC Hodges Collection, 77-1

Effigy Vessels

Vessel Form

ARAS/HSU Digital Photo No.

Type

Decoration

Rim :: Body

Paste

Temper

Color, Core

Color, Exterior

Color, Interior

Vessel Overall Height $(\mathrm{cm})$

Vessel Overall Weight (g)

Vessel Maximum Diameter $(\mathrm{cm})$

Volume (liters)

Use/Wear/Condition

Shape/Description

Lip Treatment/Shape/Angle

Orifice Diameter $(\mathrm{cm})$

Rim/Neck Height $(\mathrm{cm})$

Rim/Neck Thickness (cm)

Rim/Neck Shape/Angle

Rim/Neck Surface/Decorative Treatment Body Maximum Diameter $(\mathrm{cm})$

Body Height (cm)

Body Thickness (cm)

Body Surface/Decorative Treatment

Body Shape

Base Shape/Curvature

Base Diameter $(\mathrm{cm})$

Base Height

Base Surface/Decorative Treatment

Appendages/Handles

Notes

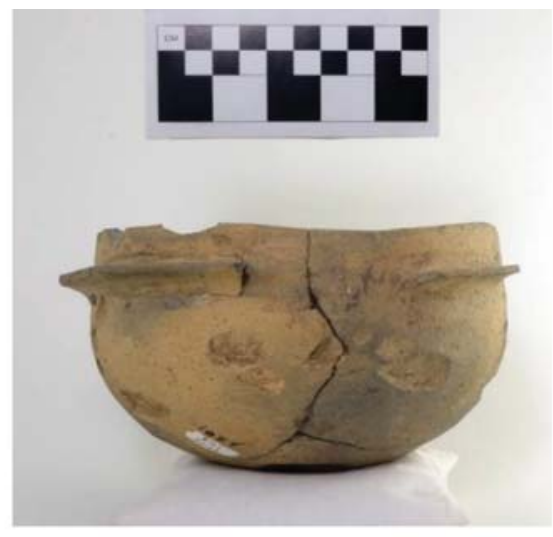

HARD, COMPACT, SMOOTH, MICA

SHELL (LEACHED) \& GROG, FINE/ABUNDANT

DARK GRAY (10YR4/1)

GRAY (10YR5/1), VERY PALE BROWN (10YR8/3)

VERY PALE BROWN (10YR7/4), GRAY (10YR5/1)

10.0

353.0

VESSEL RECONSTRUCTED, HOLE IN BASE OF BOWL, PORTION OF FLANGES \& HEAD

APPENDAGE MISSING / WEAR ON BASE AND INSIDE / FIRECLOUDING

EFFIGY BOWL WITH FLANGE AROUND RIM (BIRD OR FISH?)

SMOOTH/FLATTENED/NO ANGLE/0.3CM

15.3

3.0

0.5

CONCAVE/INSLANTED

SMOOTH

15.8

7.0

0.5

SMOOTHED / PLAIN

CONVEX

UNDISTINGUISHED/CONVEX

6.5

SMOOTH

APPLIQUED FLANGES BELOW LIP, 0.4CM THICK AND EXTEND 1.0CM FROM RIM/DRY PASTE INCISED LINES ON UPPER SURFACE OF FLANGES

Hodges catalog notes described as fish effigy 
JEC Hodges Collection, 77-1

Effigy Vessels

Vessel Form

ARAS/HSU Digital Photo No.

Type

Decoration

Rim :: Body

Paste

Temper

Color, Core

Color, Exterior

Color, Interior

Vessel Overall Height $(\mathrm{cm})$

Vessel Overall Weight (g)

Vessel Maximum Diameter (cm)

Volume (liters)

Use/Wear/Condition

Shape/Description

Lip Treatment/Shape/Angle

Orifice Diameter $(\mathrm{cm})$

Rim/Neck Height $(\mathrm{cm})$

Rim/Neck Thickness (cm)

Rim/Neck Shape/Angle

Rim/Neck Surface/Decorative Treatment

Body Maximum Diameter $(\mathrm{cm})$

Body Height $(\mathrm{cm})$

Body Thickness (cm)

Body Surface/Decorative Treatment

Body Shape

Base Shape/Curvature

Base Diameter (cm)

Base Height

Base Surface/Decorative Treatment

Appendages/Handles

Notes
21-72; 1006 / 3HS98

effigy bowl

N8606

engraved/appliqued/modeled

Erie 13 :: plain

HARD, COMPACT, SMOOTH

GROG, COARSE/ABUNDANT

LIGHT GRAY (10YR7/2), VERY DARK GRAY (10YR3/1)

GRAYISH BROWN (10YR5/2), VERY PALE BROWN (10YR7/3), YELLOW (10YR7/6)

LIGHT GRAY (10YR7/1)

12.5

616.0

1.2

FIRECLOUDING/SOOT ON EXTERIOR; HEAD IS RATTLE / CHIPS ON RIM, PROBE HOLE IN BASE, TAIL MENDED

CARINATED EFFIGY BOWL WITH MODELED HEAD AND TAIL TAB

SMOOTH/ROUNDED/SLIGHTLY EVERTED/0.2CM

14.6

6.0

0.6

CONCAVE/INSLANTED

BURNISHED; 5 ENGRAVED HORIZONTAL LINES 1.0CM BELOW LIP AND BETWEEN 0.5-0.8CM APART, IRREGULAR

16.8

3.5

0.7

BURNISHED / PLAIN

CONVEX

UNDISTINGUISHED

HEAD AND TAIL AT LIP. THE HEAD IS ANGLAR REPRESENTING A BIRD WITH A BEAK. THE TAIL IS FLAT AND ROUNDED. RATTLE IN HEAD.

Hodges catalog notes: "Bowl - effigy - rim - 5 lines - rattle handled" 
JEC Hodges Collection, 77-1

Effigy Vessels

Vessel Form

ARAS/HSU Digital Photo No.

Type

Decoration

Rim :: Body

Paste

Temper

Color, Core

Color, Exterior

Color, Interior

Vessel Overall Height (cm)

Vessel Overall Weight (g)

Vessel Maximum Diameter $(\mathrm{cm})$

Volume (liters)

Use/Wear/Condition

Shape/Description

Lip Treatment/Shape/Angle

Orifice Diameter $(\mathrm{cm})$

Rim/Neck Height $(\mathrm{cm})$

Rim/Neck Thickness (cm)

Rim/Neck Shape/Angle

Rim/Neck Surface/Decorative Treatment Body Maximum Diameter (cm)

Body Height $(\mathrm{cm})$

Body Thickness (cm)

Body Surface/Decorative Treatment

Body Shape

Base Shape/Curvature

Base Diameter $(\mathrm{cm})$

Base Height

Base Surface/Decorative Treatment

Appendages/Handles

Notes
21-136; 85 / 3HS98

effigy bottle

1250

Keno Trailed/Means Engraved

incised/engraved/appliqued/modeled

plain :: Baker 27?

HARD, SILTY, COMPACT

SHELL (LEACHED) \& GROG, FINE/SPARSE

VERY DARK GRAY (10YR3/1), GRAY (10YR5/1), PINK (7.5YR7/3)

19.3

570.0

RECONSTRUCTED WITH GLUE AND CLAY (DESIGN WAS RE-DRAWN THERE); APPEARS TO HAVE BEEN MENDED MORE THAN ONCE

BOTTLE, SQUAT, WITH PEDESTAL BASE, SPOOL NECK AND HUMAN FACE EFFIGY ON SURFACE OF BODY

ROUNDED/FLARED/THICKENED

4.8

5.8

0.5

SPOOLBULBOUS

SMOOTHED \& BURNISHED

16.8

13.5

0.5

SMOOTHED \& BURNISHED / 2 HUMAN FACE EFFIGY DESIGN SEPARATED BY SWIRLED PANELS / INCISED LINES WITH NODES FOR EYES, NOSE, MOUTH, EARS, AND ENGRAVED CROSSHATCHING; ENGRAVED TICKED LINES ON LOWER BODY

LOW-WAIST

PEDESTAL WITH CIRCULAR/CONVEX BASE

11.0

3.0

Hodges catalog notes described as human effigy, restored; Hodges 85 described as 3-legged bottle and 87 as human effigy engraved bottle; Phillips photo 3570; previous illustration Suhm \& Jelks 1962: Plate 53F; Deceiper phase 
JEC Hodges Collection, 77-1

Effigy Vessels

Vessel Form

ARAS/HSU Digital Photo No.

Type

Decoration

Rim :: Body

Paste

Temper

Color, Core

Color, Exterior

Color, Interior

Vessel Overall Height $(\mathrm{cm})$

Vessel Overall Weight (g)

Vessel Maximum Diameter $(\mathrm{cm})$

Volume (liters)

Use/Wear/Condition

Shape/Description

Lip Treatment/Shape/Angle

Orifice Diameter $(\mathrm{cm})$

Rim/Neck Height $(\mathrm{cm})$

Rim/Neck Thickness (cm)

Rim/Neck Shape/Angle

Rim/Neck Surface/Decorative Treatment

Body Maximum Diameter (cm)

Body Height $(\mathrm{cm})$

Body Thickness (cm)

Body Surface/Decorative Treatment

Body Shape

Base Shape/Curvature

Base Diameter $(\mathrm{cm})$

Base Height

Base Surface/Decorative Treatment

Appendages/Handles

Notes

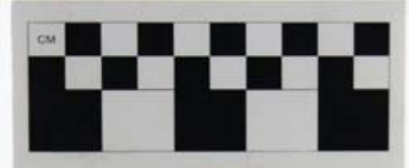

23-9; 575 / 3HS3

effigy handle, fragment

N2815

modeled/appliqued handle

HARD, COMPACT, SMOOTH

GROG, MEDIUM/ABUNDANT

YELLOWISH RED (5YR5/6), PINKISH WHITE (5YR8/2), GRAY (7.5YR6/1)

LIGHT YELLOWISH BROWN (10YR6/4), GRAY (10YR5/1), YELLOWISH RED (5YR5/6)

1.8

19.0

3.5

ONLY HANDLE PRESENT

EFFIGY HANDLE, BROKEN FROM VESSEL

21.9

7.4

SMOOTHED

BROKEN EFFIGY LOOP HANDLE HAS TWO FOLDED CUP-SHAPED EARS EXTENDING FROM EITHER SIDE OF ANIMAL FACE/HEAD (DEER?)

Hodges catalog notes "Effigy animal head - fragment" 
JEC Hodges Collection, 77-1

Effigy Vessels
Type

Decoration

Rim :: Body

Paste

Temper

Color, Core

Color, Exterior

Color, Interior

Vessel Overall Height $(\mathrm{cm})$

Vessel Overall Weight (g)

Vessel Maximum Diameter $(\mathrm{cm})$

Volume (liters)

Use/Wear/Condition

Shape/Description

Lip Treatment/Shape/Angle

Orifice Diameter $(\mathrm{cm})$

Rim/Neck Height (cm)

Rim/Neck Thickness (cm)

Rim/Neck Shape/Angle

Rim/Neck Surface/Decorative Treatment Body Maximum Diameter $(\mathrm{cm})$

Body Height $(\mathrm{cm})$

Body Thickness (cm)

Body Surface/Decorative Treatment

Body Shape

Base Shape/Curvature

Base Diameter $(\mathrm{cm})$

Base Height

Base Surface/Decorative Treatment

Appendages/Handles

Notes
24-1; 131 / 3HS99

effigy bowl (?)

N4591
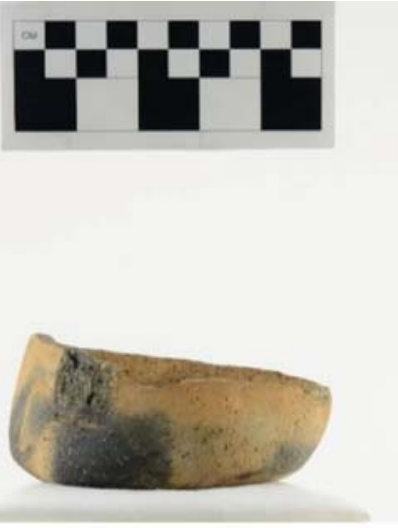

COMPACT, HARD, SMOOTH

SHELL (LEACHED), MEDIUM/ABUNDANT

GRAY (7.5YR5/1), LIGHT GRAY (7.5YR7/1)

VERY PALE BROWN (10YR7/4), VERY DARK GRAY (10YR3/1), REDDISH YELLOW (7.5YR6/6)

REDDISH YELLOW (7.5YR8/6), VERY PALE BROWN (10YR7/4), VERY DARK GRAY (10YR3/1)

5.5

118.0

11.0

0.1

DAMAGED AND SMOOTHED LIP/RIM (REUSE?), UPPER PORTION OF VESSEL MISSING; APPENDAGE BROKEN OFF

IRREGULAR TRIANGULAR-SHAPED VESSEL, PROBABLY PART OF EFFIGY/COMPOUND VESSEL
5.5
0.5

SMOOTHED EXTERIOR, IRREGULAR INTERIOR (NOT ORIGINALLY VISIBLE?) / IRREGULAR WALL SHAPE; PLAIN; FIRECLOUDING

Compound or effigy

IRREGULAR/CONVEX

10.6

Smoothed

POSSIBLE BROKEN SQUARE HANDLE ATTACHMENT ON SIDE OF VESSEL

Hodges catalog notes "Effigy bowl fragment", found with small plain bowl (and acquired by Hodges from the collector?) 
JEC Hodges Collection, 77-1

Effigy Vessels

Vessel Form

ARAS/HSU Digital Photo No.

Type

Decoration

Rim :: Body

Paste

Temper

Color, Core

Color, Exterior

Color, Interior

Vessel Overall Height (cm)

Vessel Overall Weight (g)

Vessel Maximum Diameter $(\mathrm{cm})$

Volume (liters)

Use/Wear/Condition

Shape/Description

Lip Treatment/Shape/Angle

Orifice Diameter $(\mathrm{cm})$

Rim/Neck Height (cm)

Rim/Neck Thickness (cm)

Rim/Neck Shape/Angle

Rim/Neck Surface/Decorative Treatment Body Maximum Diameter (cm)

Body Height (cm)

Body Thickness (cm)

Body Surface/Decorative Treatment

Body Shape

Base Shape/Curvature

Base Diameter $(\mathrm{cm})$

Base Height

Base Surface/Decorative Treatment

Appendages/Handles

Notes
32-1 / 3MN52

effigy bottle, quadruped

N8624

Authenticity uncertain

appliqued/modeled

HARD, COMPACT, SMOOTH

SHELL, COARSE/ABUNDANT

VERY DARK GRAY (10YR3/1), BLACK (10RY2/1), LIGHT GRAY (10YR7/1)

16.5

977.0

0.8

RECONSTRUCTION WITH PLASTER ON BODY AND BASE; HEAVY VESSEL

MODELED EFFIGY BOTTLE WITH ANIMAL HEAD (BEAR?), OPEN MOUTH WITH FANGS, EARS, EYES, SNOUT; LONG BODY, FOUR LEGS, SHORT TAIL

SMOOTHED/ROUNDED/NO ANGLE/0.5CM

6.3

OUTSLANTING NECK

24.8

6.8

2.0

SMOOTHED / PLAIN

EFFIGY/ELONGATED

UNDISTINGUISHED

HEAD IS BEARLIKE WITH OPEN MOUTH AND FANGS, EARS, EYES, SNOUT/ SHORT TAIL / FOUR LEGS WITH FLAT BASES (4.2CM HEIGHT)

based on handwritten note, purchased by Mrs. T. L. Hodges, reportedly from 3MN52, but suspected fake 
JEC Hodges Collection, 77-1

Effigy Vessels

Vessel Form

ARAS/HSU Digital Photo No.

Type

Decoration

Rim :: Body

Paste

Temper

Color, Core

Color, Exterior

Color, Interior

Vessel Overall Height $(\mathrm{cm})$

Vessel Overall Weight $(\mathrm{g})$

Vessel Maximum Diameter $(\mathrm{cm})$

Volume (liters)

Use/Wear/Condition

Shape/Description

Lip Treatment/Shape/Angle

Orifice Diameter $(\mathrm{cm})$

Rim/Neck Height $(\mathrm{cm})$

Rim/Neck Thickness (cm)

Rim/Neck Shape/Angle

Rim/Neck Surface/Decorative Treatment

Body Maximum Diameter $(\mathrm{cm})$

Body Height (cm)

Body Thickness $(\mathrm{cm})$

Body Surface/Decorative Treatment

Body Shape

Base Shape/Curvature

Base Diameter $(\mathrm{cm})$

Base Height

Base Surface/Decorative Treatment

Appendages/Handles

Notes
$34 ; 605$ / 3 HS30

effigy bowl fragment

N16610

sim. to Crockett

engraved/appliqued

Erie $2::$ Elmhurst?

HARD, COMPACT, SMOOTH, MICA

GROG, FINE/ABUNDANT, OCCASIONAL HEMATITE GRIT

BROWN (7.5YR5/3)

BROWN (7.5YR5/3-5/4), REDDISH BROWN (5YR5/4)

BROWN (7.5YR5/3)

33.2

RIMSHERD FROM EFFIGY VESSEL

MODELED WING/FIN FROM SIDE OF EFFIGY BOWL

FLAT/SMOOTHED, 0.2CM THICK

0.5

CONVEX/INSLANTED

SMOOTHED; ENGRAVED, 2 HORIZONTAL LINES (1 LINE 0.7CM BELOW LIP, 2ND $0.8 \mathrm{~cm}$ BELOW THAT)

SMOOTHED / ENGRAVED SCROLL WITH CENTRL DOT AND TICKED LINE

APPLIQUE WING OR FIN ON SIDE OF BOWL

Hodges catalog notes "pottery fragment" 
JEC Hodges Collection, 77-1

Effigy Vessels

Vessel Form

ARAS/HSU Digital Photo No.

Type

Decoration

Rim :: Body

Paste

Temper

Color, Core

Color, Exterior

Color, Interior

Vessel Overall Height $(\mathrm{cm})$

Vessel Overall Weight (g)

Vessel Maximum Diameter $(\mathrm{cm})$

Volume (liters)

Use/Wear/Condition

Shape/Description

Lip Treatment/Shape/Angle

Orifice Diameter $(\mathrm{cm})$

Rim/Neck Height (cm)

Rim/Neck Thickness (cm)

Rim/Neck Shape/Angle

Rim/Neck Surface/Decorative Treatment

Body Maximum Diameter (cm)

Body Height $(\mathrm{cm})$

Body Thickness (cm)

Body Surface/Decorative Treatment

Body Shape

Base Shape/Curvature

Base Diameter (cm)

Base Height

Base Surface/Decorative Treatment

Appendages/Handles

Notes
His

$39-1 ; 9 / 3$ HS21

effigy bowl

N8740

appliqued/modeled

HARD, COMPACT, SMOOTH, MICA

GROG \& SHELL (LEACHED), MEDIUM/ABUNDANT

GRAYISH BROWN (10YR5/2)

VERY DARK GRAY (10YR3/1), YELLOWISH RED (5YR5/6)

DARK GRAY (10YR4/1), YELLOWISH RED (5YR5/6)

4.5

178.0

10.6

0.1

PART OF THE HEAD AND LEGS ARE MISSING; SCRATCHES ON THE EXTERIOR

SHALLOW BOWL, EFFIGY APPENDAGES

SMOOTHED/ROUNDED/NO ANGLE/0.5CM

9.6

2.0

1.2

CONCAVE/OUTSLANTED

SMOOTHED; PLAIN

10.6

2.5

0.5

SMOOTHED

UNDISTINGUISHED

SMOOTH

HEAD AND LEGS ATTACHED AT RIM (BROKEN), ROUNDED TAIL AT THE OTHER END

Hodges catalog notes "small turtle effigy bowl. Head missing" 
JEC Hodges Collection, 77-1 Effigy Vessels

Vessel Form

ARAS/HSU Digital Photo No.

Type

Decoration

Rim :: Body

Paste

Temper

Color, Core

Color, Exterior

Color, Interior

Vessel Overall Height (cm)

Vessel Overall Weight (g)

Vessel Maximum Diameter $(\mathrm{cm})$

Volume (liters)

Use/Wear/Condition

Shape/Description

Lip Treatment/Shape/Angle

Orifice Diameter $(\mathrm{cm})$

Rim/Neck Height (cm)

Rim/Neck Thickness (cm)

Rim/Neck Shape/Angle

Rim/Neck Surface/Decorative Treatment Body Maximum Diameter (cm)

Body Height $(\mathrm{cm})$

Body Thickness $(\mathrm{cm})$

Body Surface/Decorative Treatment

Body Shape

Base Shape/Curvature

Base Diameter $(\mathrm{cm})$

Base Height

Base Surface/Decorative Treatment

Appendages/Handles
$\mathrm{X}-32$ / unknown

effigy bowl

1182

modeled/appliqued

SOFT, SILTY, COMPACT

GROG \& SHELL (LEACHED), COARSE/ABUNDANT

DARK GRAY (10YR4/1), REDDISH YELLOW (5YR6/6), LIGHT YELLOWISH BROWN (10YR6/4)

DARK GRAY (10YR4/1)

8.6

404.0

VESSEL INTACT EXCEPT FOR SOME SPALLING/EROSION ON THE BOTTOM AND SEVERAL CRACKS FROM THIS AREA; NO USE WEAR APPARENT EFFIGY BOWL (FISH) WITH ONE TOP FIN, FIVE BOTTOM FINS, AND ONE TAIL PLUS A WIDE MOUTH; VESSEL OPENING IN CENTER OF BODY ROUNDED LIP, DIRECT RIM

9.9

0.6

SMOOTHED; PLAIN EXCEPT FOR MODELING

16.3

8.6

0.7

SMOOTHED \& BURNISHED

EFFIGY, GLOBULAR, CONSTRICTED RIM BOWL

UNDISTINGUISHED

EFFIGY NODES FORMING 1 DORSAL FIN, TAIL, 5 VENTRAL FINS, HEAD AREA WITH LARGE CENTRAL PUNCTATION 
JEC Hodges Collection, 77-1

Effigy Vessels

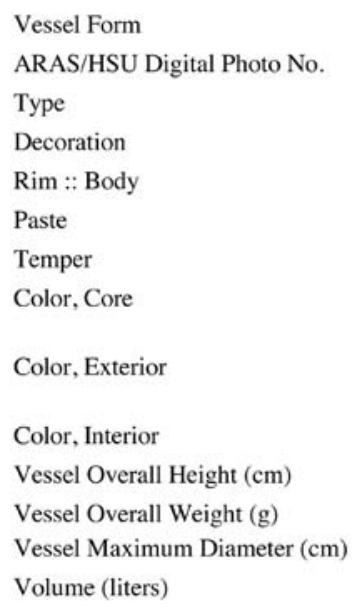

Appendages/Handles
X-34 / unknown

effigy bowl

1196

modeled/appliqued/engraved

HARD, SILTY, COMPACT, MICA

SHELL \& GROG, MEDIUM

REDDISH YELLOW (5YR6/6)

VERY DARK GRAY (10YR3/1), BROWN (10YR5/5), YELLOWISH RED (5YR5/6)

GRAYISH BROWN (10YR5/2)

8.3

364.0

OLD REPAIR WITH GLUE, SOME SHERDS MISSING; VERY ROUGH AND SLIGHTLY ERODED ON BASE; APPENDAGES MISSING (SIDES, TAIL) EFFIGY BOWL (TURTLE/FROG?) WITH HEAD/NECK APPENDAGE, OTHER APPENDAGES BROKEN OFF ROUNDED, DIRECT

11.4

0.7

SMOOTHED \& BURNISHED; EFFIGY APPENDAGES-HEAD/NECK APPENDAGE

11.6

6.5

0.8

SMOOTHED \& BURNISHED / PLAIN

EFFIGY, OPEN SIMPLE BOWL-STRAIGHT SIDED PLUS EFFIGY APPENDAGES ADDED UNDISTINGUISHED/CONVEX

EFFIGY HEAD/NECK WITH TWO NODED/ENGRAVED EYES, 3 ENGRAVED HORIZONTAL LINES RUNNING THE LENGTH OF THE HEAD/NECK, ENGRAVED WIDE FLAT MOUTH

Notes 
JEC Hodges Collection, 77-1

Effigy Vessels

Vessel Form

ARAS/HSU Digital Photo No.

Type

Decoration

Rim :: Body

Paste

Temper

Color, Core

Color, Exterior

Color, Interior

Vessel Overall Height $(\mathrm{cm})$

Vessel Overall Weight (g)

Vessel Maximum Diameter $(\mathrm{cm})$

Volume (liters)

Use/Wear/Condition

Shape/Description

Lip Treatment/Shape/Angle

Orifice Diameter $(\mathrm{cm})$

Rim/Neck Height (cm)

Rim/Neck Thickness (cm)

Rim/Neck Shape/Angle

Rim/Neck Surface/Decorative Treatment Body Maximum Diameter (cm)

Body Height $(\mathrm{cm})$

Body Thickness $(\mathrm{cm})$

Body Surface/Decorative Treatment

Body Shape

Base Shape/Curvature

Base Diameter $(\mathrm{cm})$

Base Height

Base Surface/Decorative Treatment

Appendages/Handles

Notes
$\mathrm{X}-36 ; 526 /$ unknown

effigy seed jar, quadruped

461

modeled/appliqued/incised

HARD, COMPACT

GROG \& SHELL (LEACHED), MEDIUM TO COARSE

LIGHT BROWNISH GRAY (10YR6/2)

DARK GRAYISH BROWN (10YR4/2), GRAYISH BROWN (10YR5/2), BLACK (10YR2/1)

17.5

792.0

OLD REPAIR WITH MODELING CLAY TO FRONT LEG (LEG DOES NOT CROSSMEND TO VESSEL, DOES NOT APPEAR TO BE ORIGINAL TO VESSEL); ABRADED TAIL

EFFIGY SEED JAR (BEAR) WITH 4 LEGS, TAIL, OPENING IN TOP OF HEAD DIRECT

3.3

0.7

SMOOTHED \& BURNISHED; 'PLAIN EXCEPT FACE MODELING, INTERIOR ENGRAVED CIRCLES FOR EYES

13.0

PLAIN

EFFIGY

CONVEX

\section{ATTACHED LEGS AND TAIL}

Hodges catalog notes "Bottle - bear effigy ... purchased"; previous illustration Suhm \& Jelks 1962: Plate $25 \mathrm{C}$ 
JEC Hodges Collection, 77-1

Effigy Vessels

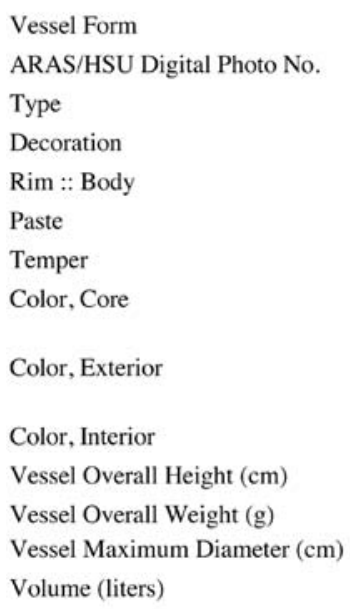

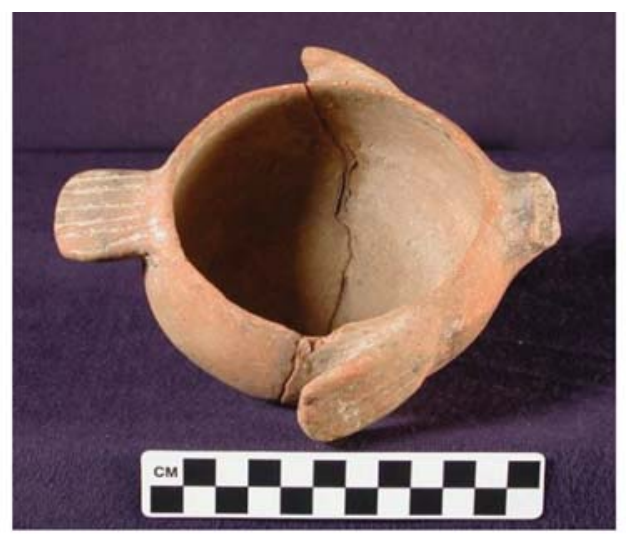

HARD, GRITTY, COMPACT

GROG, MEDIUM

GRAYISH BROWN (10YR5/2)

YELLOWISH RED (5YR5/6), RED (2.5YR5/8), REDDISH YELLOW (5YR6/6), OXIDIZED SURFACES

YELLOWISH RED (5YR5/6)

6.7

342.0

VESSEL RECONSTRUCTED WITH GLUE; HEAD AND PART OF ONE FIN/WING BROKEN OFF; SCRATCHES AROUND SIDES OF BODY ON INTERIOR, BASE WORN ON EXTERIOR; TRACES OF BLACK ON EXTERIOR (RESIDUE OR SOOTING?)

EFFIGY BOWL, HEAVY (FISH OR BIRD)

ROUNDED, THINNED

9.8

CONVEX/INSLANTED

12.0

6.7

0.6

SMOOTHED / PLAIN

SUB-GLOBULAR

CIRCULAR/FLAT

7.5

HEAD (MISSING), 2 FINS, AND TAIL FIN, DECORATED WITH INCISED LINES 
JEC Hodges Collection, 77-1

Effigy Vessels

Vessel Form

ARAS/HSU Digital Photo No.

Type

Decoration

Rim :: Body

Paste

Temper

Color, Core

Color, Exterior

Color, Interior

Vessel Overall Height $(\mathrm{cm})$

Vessel Overall Weight (g)

Vessel Maximum Diameter (cm)

Volume (liters)

Use/Wear/Condition

Shape/Description

Lip Treatment/Shape/Angle

Orifice Diameter $(\mathrm{cm})$

Rim/Neck Height $(\mathrm{cm})$

Rim/Neck Thickness (cm)

Rim/Neck Shape/Angle

Rim/Neck Surface/Decorative Treatment Body Maximum Diameter $(\mathrm{cm})$

Body Height (cm)

Body Thickness (cm)

Body Surface/Decorative Treatment

Body Shape

Base Shape/Curvature

Base Diameter $(\mathrm{cm})$

Base Height

Base Surface/Decorative Treatment

Appendages/Handles
X-68; 1305 / unknown

effigy bowl (?)

3475

appliqued

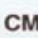

HARD, FINE, SILTY, COMPACT

SHELL (LEACHED) \& BONE?, ABUNDANT

GRAY (10YR5/1)

DARK GRAY (10YR4/1), DARK GRAYISH BROWN (10YR4/2), GRAY (10YR5/1)

VERY DARK GRAYISH BRWON (10YR3/2), GRAY (10YR5/1), BROWNISH YELLOW (10YR6/6)

4.5

102.0

ONE OF THE APPLIQUED TABS IS PARTIALLY BROKEN OFF AND THERE IS A CRACK ON SIDE; WEAR ON THE UPPER INSIDE OF VESSEL AROUND LIP

SIMPLE SHALLOW BOWL WITH APPLIQUE TABS

ROUNDED

10.9

0.4

10.9

4.5

0.4

SMOOTHED

CONICAL

FLAT

4.2

2 APPLIQUE TABS AROUND UPPER EDGE OF VESSEL, ON OPPOSITE SIDES. 
JEC Hodges Collection, 77-1

Effigy Vessels
X-186/ unknown

effigy bottle, quadruped

K5786

Means Engraved

engraved/incised/appliqued/modeled

plain :: Edith?

SOFT, COMPACT, SMOOTH

SHELL (LEACHED), MEDIUM/ABUNDANT

GRAY (10YR5/1-6/1), DARK GRAY (10YR4/1)

20.5

676.0

1.3

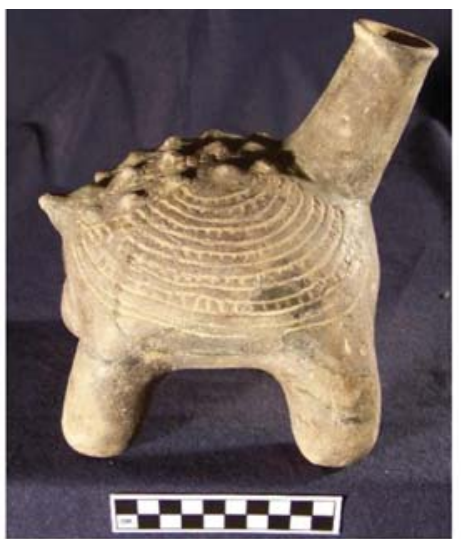

Temper

Color, Core

Color, Exterior

Color, Interior

Vessel Overall Height $(\mathrm{cm})$

Volume (liters)

Use/Wear/Condition

Shape/Description

Lip Treatment/Shape/Angle

Orifice Diameter $(\mathrm{cm})$

Rim/Neck Height (cm)

Rim/Neck Thickness (cm)

Rim/Neck Shape/Angle

Rim/Neck Surface/Decorative Treatment Body Maximum Diameter (cm)

Body Height $(\mathrm{cm})$

Body Thickness (cm)

Body Surface/Decorative Treatment

Body Shape

Base Shape/Curvature

Base Diameter $(\mathrm{cm})$

Base Height

Base Surface/Decorative Treatment

Appendages/Handles

Notes

RECONSTRUCTED; SEVERAL MISSING SHERDS ON BODY, REPAIRED WITH PLASTER IN PAST

EFFIGY BOTTLE WITH LONG NECK AND FOUR LEGS

ROUNDED/EVERTED/0.7CM

4.0

1.0

0.7

SPOOL

BURNISHED; PLAIN

15.5

11.0

BURNISHED / NODES AND INCISED HERRINGBONE LINES ON TOP OF BODY/ INCISED LINES, TICKED LINES, LADDER DESIGN ON SIDES/TRACES OF RED PIGMENT IN THE LINES

SUB-GLOBULAR/EFFIGY

CONVEX

18.0

15.7

BURNISHED

NODES ALONG THE BODY(16 IN TOTAL), TAIL, AND 4 LEGS ON THE BASE / SNAPPING TURTLE?

Previous illustration Suhm \& Jelks 1962: Plate 53K, L 
JEC Hodges Collection, 77-1

Effigy Vessels

Vessel Form

ARAS/HSU Digital Photo No.

Type

Decoration

Rim :: Body

Paste

Temper

Color, Core

Color, Exterior

Color, Interior

Vessel Overall Height $(\mathrm{cm})$

Vessel Overall Weight (g)

Vessel Maximum Diameter $(\mathrm{cm})$

Volume (liters)

Use/Wear/Condition

Shape/Description

Lip Treatment/Shape/Angle

Orifice Diameter $(\mathrm{cm})$

Rim/Neck Height (cm)

Rim/Neck Thickness (cm)

Rim/Neck Shape/Angle

Rim/Neck Surface/Decorative Treatment Body Maximum Diameter $(\mathrm{cm})$

Body Height (cm)

Body Thickness (cm)

Body Surface/Decorative Treatment

Body Shape

Base Shape/Curvature

Base Diameter $(\mathrm{cm})$

Base Height

Base Surface/Decorative Treatment

Appendages/Handles

Notes
X-187 / unknown

effigy bottle

K5830

Means Engraved

engraved/appliqued/modeled/punctated

plain :: Belhaven?

HARD, COMPACT, SMOOTH

SHELL (LEACHED), MEDIUM/SPARSE

LIGHT BROWN (7.5YR6/3), DARK GRAY (7.5YR4/1)

18.8

861.0

1.9

EXTENSIVE REPAIRS WITH MISSING SHERDS FILLED WITH PLASTER

EFFIGY BOTTLE WITH LONG NECK

SMOOTHED, ROUNDED TO ROLLED, SLIGHTLY EVERTED, 0.7CM

4.0

7.5

0.5

SPOOL

BURNISHED; PLAIN

19.0

8.0

ENGRAVED LINES, UNUSUALLY BROAD FOR ENGRAVING, PUNCTATED AT LOWER EDGE OF BODY, APPLIQUED RIDGE; IDEOSYNCRATIC DESIGN SOMEWHAT SIMILAR TO BELHAVEN IN SCROLL UNDER NECK.

OVOID/EFFIGY (TURTLE)

CONVEX

19.0

5.5

BURNISHED

TAIL ON BACK RIDGE

Previous illustration Suhm \& Jelks 1962: Plate 53A 
JEC Hodges Collection, 77-1

Effigy Vessels

\section{Vessel Form}

ARAS/HSU Digital Photo No.

Type

Decoration

Rim :: Body

Paste

Temper

Color, Core

Color, Exterior

Color, Interior

Vessel Overall Height $(\mathrm{cm})$

Vessel Overall Weight (g)

Vessel Maximum Diameter $(\mathrm{cm})$

Volume (liters)

Use/Wear/Condition

Shape/Description

Lip Treatment/Shape/Angle

Orifice Diameter $(\mathrm{cm})$

Rim/Neck Height $(\mathrm{cm})$

Rim/Neck Thickness (cm)

Rim/Neck Shape/Angle

Rim/Neck Surface/Decorative Treatment Body Maximum Diameter $(\mathrm{cm})$

Body Height $(\mathrm{cm})$

Body Thickness (cm)

Body Surface/Decorative Treatment

Body Shape

Base Shape/Curvature

Base Diameter $(\mathrm{cm})$

Base Height

Base Surface/Decorative Treatment

Appendages/Handles

Notes
$\mathrm{X}-231 ; 576 /$ unknown

effigy handle, fragment

N8871

modeled/appliqued

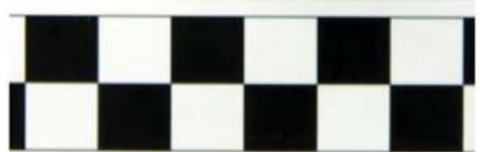

HARD, COMPACT, SMOOTH, SOME HEMATITE PEBBLES

GROG, MEDIUM/ABUNDANT

GRAY (10YR6/1), LIGHT RED (2.5YR6/8)

2.5

10.0

EARS/HORNS BROKEN OFF; BREAK WHERE ATTACHED TO RIM OF VESSEL

MODELED ANIMAL HEAD APPENDAGE

SMOOTHED / PLAIN

EFFIGY

HEAD OF SOME SORT OF ANIMAL/EYES AND MOUTH ARE INCISEDAND PUNCTATED/SHORT NECK, LONG NOSE AND FACE

Hodges catalog notes "Effigy animal head - fragment" / POSSIBLY 3HS76 OR 3HS101? 
JEC Hodges Collection, 77-1

Effigy Vessels

$X ; 2524$ / unknown

Vessel Form

effigy handle, fragment

ARAS/HSU Digital Photo No.

N8926

Type

Decoration

Rim :: Body

Paste

Temper

Color, Core

Color, Exterior

modeled/appliqued/engraved

Edgar 3

HARD, COMPACT, SMOOTH, MICA

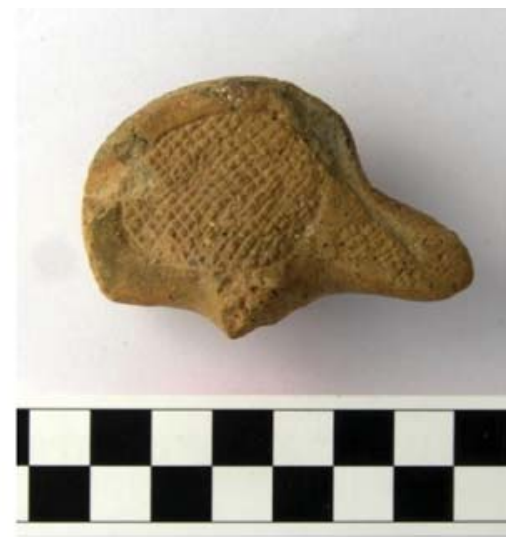

GROG \& SHELL(LEACHED), MEDIUM/ABUNDANT, OCCASIONAL GRIT

LIGHT BROWNISH GRAY (10YR6/2)

PALE BROWN (10YR6/3), DARK GRAYISH BROWN (10YR4/2)

Color, Interior

Vessel Overall Height $(\mathrm{cm})$

Vessel Overall Weight $(\mathrm{g})$

Vessel Maximum Diameter $(\mathrm{cm})$

Volume (liters)

Use/Wear/Condition

EFFIGY APPENDAGE BROKEN FROM VESSEL RIM

Shape/Description

Lip Treatment/Shape/Angle

Orifice Diameter $(\mathrm{cm})$

Rim/Neck Height $(\mathrm{cm})$

Rim/Neck Thickness (cm)

Rim/Neck Shape/Angle

Rim/Neck Surface/Decorative Treatment

Body Maximum Diameter (cm)

Body Height $(\mathrm{cm})$

6.6

Body Thickness (cm)

4.5

1.5

Body Surface/Decorative Treatment

SMOOTHED / CROSSHATCHED LINES

Body Shape

EFFIGY

Base Shape/Curvature

Base Diameter $(\mathrm{cm})$

Base Height

Base Surface/Decorative Treatment

Appendages/Handles

Notes

Previous illustration Trubitt \& Evans 2015: Fig. 6 